\title{
PUBLIC PENSIONS AND CAPITAL ACCUMUlation: THE CASE OF BRAZIL
}

\author{
GERHARD GLOMM \\ JUERGEN JUNG \\ CHANGMIN LEE \\ CHUNG TRAN
}

CESIFO WORKING PAPER No. 1539

CATEgory 5: Fiscal Policy, Macroeconomics AND Growth

SEPTEMBER 2005

An electronic version of the paper may be downloaded
- from the SSRN website: $\quad$ www.SSRN.com
- from the CESifo website: $\quad$ www.CESifo-group.de 


\title{
Public Pensions And CAPital AcCumulation: THE CASE OF BRAZIL
}

\begin{abstract}
We use an OLG model to study the effects of the generous public sector pension system in Brazil. In our model there are two types of workers, one working in the private sector, the other working in the public sector. Public workers produce infrastructure or education services. We find that reducing generosity of the public sector pensions has large effects on capital accumulation and steady state income.
\end{abstract}

JEL Code: E62, H41, H55.

Keywords: pension reform, capital accumulation.

Gerhard Glomm

Department of Economics

Wylie Hall, Indiana University

Bloomington, IN 47405

USA

gglomm@indiana.edu

Changmin Lee

Department of Economics

Wylie Hall, Indiana University

Bloomington, IN 47405

USA

\author{
Juergen Jung \\ Department of Economics \\ Wylie Hall, Indiana University \\ Bloomington, IN 47405 \\ USA \\ Chung Tran \\ Department of Economics \\ Wylie Hall, Indiana University \\ Bloomington, IN 47405 \\ USA
}

We would like to thank participants of the CESifo Conference on Pension Reform in Copenhagen, especially Alexander Kemnitz, Michele Boldrin and Harrie Verbon for helpful comments. 


\section{Introduction}

Brazil runs two very different pension systems for the public and the private sector. The public sector system is very generous. "Integrality" ensures that pension payments are $100 \%$ of the highest income of a public sector employee. "Parity" makes sure that these pension payments are indexed to wages paid to current civil servants. Overall, the public sector pension system accounts for $50 \%$ of all retirement payments, whereas public sector retirees only account for $5 \%$ of all retirees in Brazil. The average contribution rate of civil servants towards their pension fund is $11 \%$. In the private sector the contribution rates are much higher, roughly $27 \%$ (7.6\% employees contribution and $20 \%$ employer contribution) in the manufacturing and service sector. In the agricultural (rural) sector contribution rates are somewhat lower and range around $16 \%$. The average pension paid to private sector retirees amounts to $70 \%$ to $80 \%$ of their wage income. ${ }^{1}$ According to Souza et al. (2004) the deficit of the pension system amounts to roughly $4.5 \%$ of GDP, $3.5 \%$ is caused by the public sector, the remaining $1 \%$ comes from the private sector.

The generosity of the public sector pension system has led to concerns about its sustainability. These concerns inspired the original bill of the Constitutional Amendment 40 (Lula Reform 2003) which had two main objectives. First, it aimed at reducing the huge deficit in the civil sector pension system. Second, it aimed at making the public system more similar to the private sector system to improve equity. The changes that were actually approved fell short of the original goals and mainly affect future public servants. $^{2}$

This paper studies the effects of public sector pension reforms on capital accumulation. We do this using an OLG framework, which is described in detail in section 2, in which the government hires workers and invests in a public capital to provide services to households and firms. These services are made available free of charge. We can think of these as being services flowing from the stock of roads and highways.

The government also finances public expenditures on education and social security payments to the private sector workers. In our model financing generous public sector pensions implies the opportunity cost of lower public expenditures on public education and/or on public capital accumulation. We focus on reduction of public sector pensions. The extra resources freed up by cutting public sector pensions can be used to $(i)$ increase private sector pension, $(i i)$ increase public education expenditure, or (iii) increase investment in the public capital stock.

Section 3 contains the definition of competitive equilibrium. In section 4 we solve the model. In section 5 we calibrate the model to Brazil and in section 6 we conduct policy experiments. In all of the policy experiments conducted we focus on steady state outcomes. We find that steady state income is completely unaffected by shifting from public to private sector pensions. This is due to homogeneity of the utility function assumed here. Decreasing generosity of public sector pensions and increasing either public education expenditures or investment in public capital has sizeable effects on

\footnotetext{
${ }^{1}$ See Bonturi (2002) for more detailed information about the Brazilian pension system.

${ }^{2}$ Souza et al. (2004) contains further details of the pension reform in Brazil.
} 
steady state income. We find that the direct effects of public pension reform through influencing savings are small. However, using the resources that become available through reduction in public pensions on public investment in infrastructure or on public education has large effects on steady state income. We conduct extensive sensitivity analysis for these policy reform experiments. Section 7 concludes.

\section{The Model}

In order to study the economic effects of the generosity of public sector pensions we employ a model in which recipients of public sector pensions, civil servants, play a meaningful economic role. In our model civil servants work in two sectors, public education and public provision of infrastructure. This set-up allows us to not only study the costs of public sector compensation including pension benefits but also the benefits of public sector employment.

There is a large number of individuals who live for two periods in an OLG set-up. Each period accounts for roughly 30 years. For reasons of simplicity we abstract from population growth and normalize the size of the population to one. A fraction $N^{r}$ of the population is working in the private sector and $N^{u}$ is the fraction of civil servants. Workers who work in the public sector but do not have the status of a civil servant are counted as private sector workers. Only civil servants have access to generous pension payments. We therefore get

$$
N^{r}+N^{u}=1 .
$$

A fraction $N^{u e}$ of civil servants is working in the public education sector , the others $N^{u i}$ are working in the "public infrastructure" sector. We use the following notation

$$
\begin{aligned}
N^{u e} & =a N^{u}, \\
N^{u i} & =(1-a) N^{u} .
\end{aligned}
$$

All civil servants have an identical wage and pension scheme regardless of sector of employment. This scheme differs from private sector workers in contribution rates and also in benefit payments.

Agents value two different types of goods, a privately provided good and a publicly provided good. The utility function of a member of generation $t$ is

$$
\begin{aligned}
& u\left(c_{t}, G_{t}, c_{t+1}, G_{t+1}\right) \\
= & \frac{1}{1-\sigma}\left[\left(c_{t}^{\rho}+\Theta G_{t}^{\rho}\right)^{\frac{1}{\rho}}\right]^{1-\sigma}+\beta \frac{1}{1-\sigma}\left[\left(c_{t+1}^{\rho}+\Theta G_{t+1}^{\rho}\right)^{\frac{1}{\rho}}\right]^{1-\sigma},
\end{aligned}
$$

where $c_{s}$ is consumption of the private good, and $G_{s}$ is a pure public good provided by the government in the two respective periods $s=t, t+1$. We can think of this public good as enforcement of private property, enforcement of contracts, maintenance of law and order. Alternatively, we can think of this good as roads, highways or other elements of core infrastructure which is made available to all households and firms at a zero price. We also assume $\rho \leq 1$ and $\sigma>0$. 
The privately supplied good is produced from three inputs, the publicly provided service $G_{t}$, the private capital stock $K_{t}$ and effective labor (human capital) in the private sector $H_{t}^{r}=H_{t} N_{t}^{r}$ according to the production function

$$
Y_{t}=A G_{t}^{\alpha_{1}} K_{t}^{\alpha_{2}}\left(H_{t}^{r}\right)^{\alpha_{3}},
$$

where $\alpha_{i} \in(0,1)$ for $i=1,2,3, \alpha_{2}+\alpha_{3}=1$, and $A>0$. Capital $K$ fully depreciates each period. The public good $G$ is provided without charge by the government. If $G$ is made available to firms at a zero price, firms only hire capital and labor. The condition $\alpha_{2}+\alpha_{3}=1$ then ensures constant returns to scale in the two hired factors and zero profits. This kind of production function is standard and has been used by Barro (1990), Glomm and Ravikumar (1994), Turnovsky and Fisher (1995), Cassou and Lansing (1998) and many others.

Human capital is produced according to

$$
h_{t+1}=B\left[\left(H_{t}^{u e}\right)^{\eta_{1}}+\chi_{1} E_{t}^{\eta_{1}}\right]^{\frac{\gamma_{1}}{\eta_{1}}} h_{t}^{\gamma_{2}}
$$

where $H_{t}^{u e}$ is public educational human capital (teachers), $E_{t}$ is public education expenditure, $h_{t}$ is the parental human capital, $B>0, \eta_{1} \leq 1,\left(\gamma_{1}, \gamma_{2}\right) \in(0,1)$, and $\gamma_{1}+\gamma_{2} \leq 1$.

Most models of human capital accumulation such as Loury (1981), Benabou (1996), Fernandez and Rogerson (1998) or Blankenau and Simpson (2004) only allow for one public input into human capital production. Here we find it useful to disaggregate public education inputs into teachers $H_{t}^{u e}$ and material inputs $E_{t}$ such as textbooks, computers and buildings.

The government uses effective labor (human capital) of civil servants employed in the non-educational sector $H_{t}^{u i}=H_{t} N_{t}^{u i}=H_{t}(1-a) N_{t}^{u}$ and public capital $K_{t}^{G}$ to produce services according to

$$
G_{t}=Y_{t}^{G}=Z\left[\left(K_{t}^{G}\right)^{\eta_{2}}+\chi_{2}\left(H_{t}^{u i}\right)^{\eta_{2}}\right]^{1 / \eta_{2}}
$$

where $Z>0$ and $\eta_{2} \leq 1$. Public capital evolves according to

$$
K_{t+1}^{G}=\left(1-\delta_{K^{G}}\right) K_{t}^{G}+I_{t}^{G} .
$$

The government collects two kinds of labor income taxes in the public sector, the standard tax on labor income $\tau_{L t}^{u}$ and an additional social security contribution rate $\tau_{L t}^{s s u}$. Workers in the private sector pay the tax rates $\tau_{L t}^{r}$ and $\tau_{L t}^{s s r}$. In addition, capital income is taxed at rate $\tau_{K t}$. The stock of debt that the government can issue in period $t$ is $B_{t}$. In period $t$ the government faces the following expenditures (where we will express expenditures for government program $i$ as fixed share $\Delta_{i, t}$ of output $Y_{t}$ ):

1. public education expenditures

$$
E_{t}=\Delta_{E, t} Y_{t}
$$


2. investments in public capital

$$
I_{t}^{G}=\Delta_{G, t} Y_{t},
$$

3. transfer payments to the old who were employed in the private sector

$$
T_{t}^{r}=\Delta_{T^{r}, t} Y_{t}
$$

4. wage payments of the current civil servants $w_{t}^{u} H_{t} N_{t}^{u}$,

5. pensions of last period's civil servants $\Psi w_{t}^{u} H_{t} N_{t-1}^{u}$,

6. payments of public debt $\left(1+r_{t}\right) B_{t}$.

Public pensions are indexed to this period's public sector wages, where $w_{t}^{u} H_{t}$ is an individual public employee's wage income. The total wage bill of the public sector in a given period is $w_{t}^{u} H_{t} N_{t}^{u}$. Since $w_{t}^{u} H_{t}$ is the average wage of an individual agent in a period (which is roughly 30 years long), the question arises what fraction of this current wage is paid out to retirees. In order to capture different levels of generosity of a pension system we express the amount of pensions paid to public sector retirees as

$$
T_{t}^{u}=\Psi w_{t}^{u} H_{t} N_{t-1}^{u}
$$

where $\Psi>0$. If $\Psi \in(0,1)$ then pensions paid are only a fraction of the current average wage. The larger $\Psi$ becomes the more generous the public pension system becomes. As $\Psi>1$ the pensions paid are actually higher than current average wages. ${ }^{3}$ In order to calculate the total amount of public pensions paid to retired civil servants we multiply the individual wage of a current civil servant $w_{t}^{u} H_{t}$ by the number of public sector retirees (the public employees of the previous period) $N_{t-1}^{u}$ and by the generosity factor $\Psi$. The government budget constraint can be written as

$$
\begin{aligned}
& \left(1+r_{t}\right) B_{t}+\Delta_{E, t} Y_{t}+\Delta_{G, t} Y_{t}+\overbrace{\Delta_{T^{r}, t} Y_{t}}^{\text {private pension }} T^{r}+\overbrace{w_{t}^{u} H_{t} N_{t}^{u}}^{\text {public wages }}+\overbrace{\Psi w_{t}^{u} H_{t} N_{t-1}^{u}}^{\text {public pension } T^{u}} \\
= & B_{t+1}+\left(\tau_{L, t}^{s s u}+\tau_{L, t}^{u}\right) w_{t}^{u} H_{t} N_{t}^{u}+\left(\tau_{L, t}^{s s r}+\tau_{L, t}^{s s r f}+\tau_{L, t}^{r}\right) w_{t}^{r} H_{t} N_{t}^{r}+\tau_{K, t} r_{t} K_{t} .
\end{aligned}
$$

We assume that government behavior is exogenous, that is labor taxes $\tau_{L t}^{u}, \tau_{L, t}^{r}, \tau_{L, t}^{s s u}, \tau_{L, t}^{s s r}$, a contribution rate to social security paid by the firm $\tau_{L, t}^{s s f}$, capital taxes $\tau_{K, t}$, the fraction spent on education $\Delta_{E, t}$, the fraction spent on increasing the public capital stock $\Delta_{G, t}$, the fraction that goes to retired private sector employees $\Delta_{T, t}$, the parameter of generosity of the public pension system $\Psi$ are all exogenous.

\footnotetext{
${ }^{3}$ Since wages in the data are rising with age and in the model wages are constant over the entire period, we will use values of $\Psi$ around 1.5 to capture "integrality".
} 


\section{Equilibrium}

\subsection{Household Problem}

We can now state the household problem as

$$
\begin{aligned}
\max _{c_{t}^{j}, c_{t+1}^{j}, i_{t+1}^{j}} \frac{1}{1-\sigma}\left[\left(\left(c_{t}^{j}\right)^{\rho}+\Theta G_{t}^{\rho}\right)^{\frac{1}{\rho}}\right]^{1-\sigma}+\beta \frac{1}{1-\sigma}\left[\left(\left(c_{t+1}^{j}\right)^{\rho}+\Theta G_{t+1}^{\rho}\right)^{\frac{1}{\rho}}\right]^{1-\sigma} \\
\text { s.t. } \\
c_{t}^{j}+i_{t}^{j} \leq \mathcal{I}_{t}^{j} \\
c_{t+1}^{j} \leq R_{t+1} i_{t}^{j}+\frac{T_{t+1}^{j}}{N_{t}^{j}}
\end{aligned}
$$

where, $j=u$ if it is a public sector worker, $j=r$ if it is a private sector worker, $i_{t}=k_{t+1}+b_{t+1}$ is the agent's savings in form of physical capital or government bonds,

$$
\mathcal{I}_{t}^{j}=\left(1-\tau_{L t}^{s s j}-\tau_{L t}^{j}\right) w_{t}^{j} h_{t}
$$

is after-tax wage income of agent $j$ when young, $R_{t+1}$ is the gross rate of return on investments, and $T_{t+1}^{j}$ is a government transfer received when old. ${ }^{4}$ Household $j$ takes the level of the public good $G_{t}$ as well as all tax rates and prices as given.

\subsection{Firm Problem}

The firm's problem is standard. Note, however, that the firm takes the level of the public good as given so that the firm only chooses to hire physical capital and human capital. Note also that the government collects a social security tax from the firm at the rate $\tau_{t}^{s s r f}$. Thus the firm's problem is

$$
\max _{\left(H_{t}^{r}, K_{t}\right)} F\left(G_{t}, K_{t}, H_{t}^{r}\right)-\left(1+\tau_{t}^{s s r f}\right) w_{t}^{r} H_{t}^{r}-r_{t}^{k} K_{t} .
$$

\subsection{Definition of Equilibrium}

Given the government policy $\left\{\tau_{L t}^{r}, \tau_{L t}^{u}, \tau_{L t}^{s s r}, \tau_{L t}^{s s u}, \tau_{L t}^{s s r}, \tau_{K t}, \Delta_{E, t}, \Delta_{K^{G}, t}, \Delta_{T, t}, w_{t}^{u}, N_{t}^{u}, \Psi\right\}_{t=0}^{\infty}$, a competitive equilibrium is a collection of sequences of decisions of privately employed households $\left\{c_{t}^{r}, c_{t+1}^{r}, k_{t+1}^{r}, b_{t+1}^{r}, h_{t+1}^{r}\right\}_{t=0}^{\infty}$, sequences of decisions of publicly employed households $\left\{c_{t}^{u}, c_{t+1}^{u}, k_{t+1}^{u}, b_{t+1}^{u}, h_{t+1}^{u}\right\}_{t=0}^{\infty}$, sequences of aggregate stocks of private physical capital and private human capital $\left\{K_{t}, H_{t}^{r}\right\}_{t=0}^{\infty}$, sequences of aggregate stocks of public physical capital and public human capital $\left\{K_{t}^{G}, H_{t}^{u}\right\}_{t=0}^{\infty}$, sequences of factor prices $\left\{w_{t}^{r}, r_{t+1}^{k}, r_{t+1}^{b}\right\}_{t=0}^{\infty}$ such that

\footnotetext{
${ }^{4}$ The wage of an agent of group $j$ is $w_{t}^{j} h_{t}$. We assume that human capital in the public and private sector is the same, only the fraction employed will differ, so that in the aggregate we will have $h_{t}=H_{t}$ and the fraction employed by the private sector is $H_{t} N_{t}^{r}$ and the fraction employed by the public sector is $H_{t} N_{t}^{u}$.
} 
(i) the sequence $\left\{c_{t}^{r}, c_{t+1}^{r}, k_{t+1}^{r}, b_{t+1}^{r}, h_{t+1}^{r}\right\}_{t=0}^{\infty}$ solves the maximization problem of the privately employed household (9) with $j=r$ and the sequence $\left\{c_{t}^{u}, c_{t+1}^{u}, k_{t+1}^{u}, b_{t+1}^{u}, h_{t+1}^{u}\right\}_{t=0}^{\infty}$ solves the maximization problem of the publicly employed household (9) with $j=u$;

(ii) factor prices are determined by

$$
\begin{aligned}
r_{t+1}^{k} & =\alpha_{2} \frac{Y_{t+1}}{K_{t+1}} \\
w_{t}^{r} & =\frac{\alpha_{3}}{\left(1+\tau_{t}^{s s r f}\right)} \frac{Y_{t}}{H_{t}^{r}}=\frac{\alpha_{3}}{\left(1+\tau_{t}^{s s r f}\right)} \frac{Y_{t}}{\left(1-N_{t}^{u}\right) H_{t}} \\
R_{t} & =r_{t}^{b}=\left(1-\tau_{t}^{k}\right) r_{t}^{k}+1-\delta^{k}
\end{aligned}
$$

(iii) capital markets clear, so that aggregate capital stocks are given by

$$
\begin{aligned}
I_{t} & =i_{t}^{r}\left(1-N_{t}^{u}\right)+i_{t}^{u} N_{t}^{u}=K_{t+1}+B_{t+1}, \\
H_{t} & =H_{t}\left(1-N_{t}^{u}\right)+H_{t} N_{t}^{u}=H_{t}^{r}+H_{t}^{u},
\end{aligned}
$$

(iv) commodity markets clear

$$
\begin{aligned}
C_{t-1}^{r}+C_{t}^{r}+C_{t-1}^{u}+C_{t}^{u}+K_{t+1}+I_{t}^{G}+E_{t} & =Y_{t}, \\
G_{t} & =Y_{t}^{G},
\end{aligned}
$$

(vi) and the government budget constraint (8) holds.

\section{Solving the Model}

We assume that the government indexes public worker wages to private worker wages as following

$$
w_{t}^{u}=\xi w_{t}^{r} .
$$

We typically restrict $\xi$ to be sufficient large so that we can assume that the government can directly set the fraction of the workforce $N_{t}^{u}$ it wants to employ. Then total human capital employed by the public sector is $H_{t}^{u}=H_{t} N_{t}^{u}$. All other workers $\left(1-N_{t}^{u}\right)$ will work in the private sector, that is $H_{t}^{r}=H_{t} N_{t}^{r}=H_{t}\left(1-N_{t}^{u}\right)$. We justify this by assuming that agents would prefer to work for the government if lifetime income from working in the public sector exceeds lifetime income from working in the private sector.

Households can invest in two assets, physical capital and government issued bonds. In equilibrium both assets have to pay the same rate of return due to non-arbitrage conditions. If we denote $R_{t+1}^{k}=\left(1-\tau_{K t+1}\right) r_{t+1}^{k}+1-\delta$ as the after-tax return on capital investment and $R_{t+1}^{b}=\left(1+r_{t+1}^{b}\right)$ as the net return on bonds, we get

$$
\left(1-\tau_{K t+1}\right) r_{t+1}^{k}+1-\delta=1+r_{t+1}^{b}=R_{t+1} .
$$


If we assume full depreciation, $\delta=1$ this becomes

$$
\left(1-\tau_{K t+1}\right) r_{t+1}^{k}=R_{t+1}
$$

After substituting the budget constraints into the utility function we get the following maximization problem for the households:

$$
\max _{\left\{i_{t}^{j}\right\}}\left\{\begin{array}{c}
\frac{1}{1-\sigma}\left[\left(\left(\mathcal{I}_{t}^{j}-i_{t}^{j}\right)^{\rho}+\Theta G_{t}^{\rho}\right)^{\frac{1}{\rho}}\right]^{1-\sigma} \\
+\beta \frac{1}{1-\sigma}\left[\left(\left(R_{t+1} i_{t}^{j}+T_{t+1}^{j}\right)^{\rho}+\Theta G_{t+1}^{\rho}\right)^{\frac{1}{\rho}}\right]^{1-\sigma}
\end{array}\right\} .
$$

The first order condition for this problem is

$$
\begin{aligned}
& {\left[\left(\mathcal{I}_{t}^{j}-i_{t}^{j}\right)^{\rho}+\Theta G_{t}^{\rho}\right]^{\frac{1-\sigma}{\rho}-1}\left(\mathcal{I}_{t}^{j}-i_{t}^{j}\right)^{\rho-1} } \\
= & \beta R_{t+1}\left[\left(R_{t+1} i_{t}^{j}+\frac{T_{t+1}^{j}}{N^{j}}\right)^{\rho}+\Theta G_{t+1}^{\rho}\right]^{\frac{1-\sigma}{\rho}-1}\left(R_{t+1} i_{t}^{j}+\frac{T_{t+1}^{j}}{N^{j}}\right)^{\rho-1} .
\end{aligned}
$$

We cannot get any closed form solution for $i_{t}^{j}$ unless we make some more assumptions about parameters $\rho$ and $\sigma$.

\subsection{Cobb-Douglas within Period $(\rho=0)$ and no Government Debt}

When $\rho \rightarrow 0$ then expression (9) reduces to a Cobb-Douglas form and after substituting the budget constraint this problem becomes

$$
\max _{\left\{i_{t}^{j}\right\}}\left\{\frac{1}{1-\sigma}\left[\left(\mathcal{I}_{t}^{j}-i_{t}^{j}\right)^{\theta} G_{t}^{1-\theta}\right]^{1-\sigma}+\beta \frac{1}{1-\sigma}\left[\left(R_{t+1} i_{t}^{j}+\frac{T_{t+1}^{j}}{N_{t}^{j}}\right)^{\theta} G_{t+1}^{1-\theta}\right]^{1-\sigma}\right\},
$$

where $\theta \equiv \frac{1}{1+\Theta}$. We can now derive first order conditions and get

$$
\left(\mathcal{I}_{t}^{j}-i_{t}^{j}\right)^{\theta(1-\sigma)-1}=\beta R_{t+1}\left(R_{t+1} i_{t}^{j}+\frac{T_{t+1}^{j}}{N_{t}^{j}}\right)^{\theta(1-\sigma)-1}\left(\frac{G_{t+1}}{G_{t}}\right)^{(1-\theta)(1-\sigma)} .
$$

The optimal decision rules for savings and consumption are

$$
\begin{aligned}
i_{t}^{j} & =\frac{\mathcal{I}_{t}^{j}-\mathcal{C}_{t} \frac{T_{t+1}^{j}}{N_{t}^{j}}}{1+\mathcal{C}_{t} R_{t+1}}, \\
c_{t}^{j} & =\frac{\mathcal{C}_{t} R_{t+1} \mathcal{I}_{t}^{j}+\mathcal{C}_{t} \frac{T_{t+1}^{j}}{N_{t}^{j}}}{1+\mathcal{C}_{t} R_{t+1}}, \\
c_{t+1}^{j} & =\frac{R_{t+1} \mathcal{I}_{t}^{j}+\frac{T_{t+1}^{j}}{N_{t}^{j}}}{1+\mathcal{C}_{t} R_{t+1}},
\end{aligned}
$$


where, $\mathcal{C}_{t}=\left[\beta R_{t+1}\left(\frac{G_{t+1}}{G_{t}}\right)^{(1-\theta)(1-\sigma)}\right]^{\frac{1}{\theta(1-\sigma)-1}}$. We now impose the steady state. The expressions for savings by private and public sector workers become

$$
\begin{aligned}
i^{r} & =\frac{\left(1-\tau_{L}^{s s r}-\tau_{L}\right) \frac{\alpha_{3}}{\left(1+\tau_{t}^{s s r f}\right)\left(1-N^{u}\right)} Y-\mathcal{C} \frac{\Delta_{T^{r}}}{1-N^{u}} Y}{1+\mathcal{C} R}, \\
i^{u} & =\frac{\left(1-\tau_{L}^{s s u}-\tau_{L}^{u}\right) \xi \frac{\alpha_{3}}{\left(1+\tau_{t}^{s s r f}\right)\left(1-N^{u}\right)} Y-\mathcal{C} \Psi \xi \frac{\alpha_{3}}{\left(1+\tau_{t}^{s s r f}\right)\left(1-N^{u}\right)} Y}{1+\mathcal{C} R} .
\end{aligned}
$$

Adding private and public investment we get an expression for aggregate capital (assuming no public debt)

$$
\begin{aligned}
K & =N^{u} i^{u}+\left(1-N^{u}\right) i^{r} \\
& =\frac{Y}{1+\mathcal{C} R}\left\{\left(\frac{N^{u}}{1-N^{u}}\right) \frac{\xi \alpha_{3}}{1+\tau_{t}^{s s r f}}\left[\left(1-\tau_{L}^{s s u}-\tau_{L}^{u}\right)-\mathcal{C} \Psi\right]+\left(1-\tau_{L}^{s s r}-\tau_{L}^{r}\right) \frac{\alpha_{3}}{1+\tau_{t}^{s s r f}}-\mathcal{C} \Delta_{T^{r}}\right\} .
\end{aligned}
$$

We next use the expression $R=\alpha_{2}\left(1-\tau_{K}\right) \frac{Y}{K}$ from the firm's first order condition (12) and replace the left hand side to get

$$
\alpha_{2}\left(1-\tau_{K}\right) \frac{1}{R}=\frac{1}{1+\mathcal{C} R}\left\{\begin{array}{c}
\frac{N^{u}}{1-N^{u}} \xi \frac{\alpha_{3}}{1+\tau_{t}^{s s r f}}\left[\left(1-\tau_{L}^{s s u}-\tau_{L}^{u}\right)-\mathcal{C} \Psi\right] \\
+\left(1-\tau_{L}^{s s r}-\tau_{L}^{r}\right) \frac{\alpha_{3}}{1+\tau_{t}^{s s r f}}-\mathcal{C} \Delta_{T^{r}}
\end{array}\right\},
$$

where we know that $\mathcal{C}=[\beta R]^{\frac{1}{\theta(1-\sigma)-1}}$ is a function of steady state $R$. Then we solve this equation for $R$. We can now calculate the remaining steady state values.

From (1) we get an expression for output in terms of human capital

$$
h_{t+1}=B\left[\left(H_{t}^{u e}\right)^{\eta_{1}}+\chi_{1} E_{t}^{\eta_{1}}\right]^{\frac{\gamma_{1}}{\eta_{1}}} h_{t}^{\gamma_{2}}
$$

In the steady state this becomes

$$
\left(\frac{H^{1-\gamma_{2}}}{B}\right)^{\eta_{1} / \gamma_{1}}=\left(a N^{c} H\right)^{\eta_{1}}+\chi_{1}\left(\Delta_{E} Y\right)_{t}^{\eta_{1}}
$$

which can be solved for ${ }^{5}$

$$
\bar{Y}(H)=\frac{1}{\Delta E}\left[\frac{\left(\frac{H^{1-\gamma_{2}}}{B}\right)^{\eta_{1} / \gamma_{1}}-\left(a N^{u} H\right)^{\eta_{1}}}{\chi_{1}}\right]^{\frac{1}{\eta_{1}}} .
$$

\footnotetext{
${ }^{5}$ Note, due to this formulation we can only solve for cases where $\eta_{1} \geq 0$, since then $\left[\left(\frac{H^{1-\gamma_{2}}}{B}\right)^{\eta_{1} / \gamma_{1}}-\left(a N^{u} H\right)^{\eta_{1}}\right] \geq 0$. If $\eta_{1}$ becomes negative, that is $H^{u e}$ and $E$ are complements, the term $\left[\left(\frac{H^{1-\gamma_{2}}}{B}\right)^{\eta_{1} / \gamma_{1}}-\left(a N^{u} H\right)^{\eta_{1}}\right]$ becomes negative and solutions do not exist.
} 
Given $R$ we have

$$
\bar{K}(H, R)=\frac{\left(1-\tau_{K}\right) \alpha_{2}}{R} \bar{Y}(H) .
$$

Since at steady state $K_{t+1}^{G}=K_{t}^{G}=K^{G}$, and using (5) in the law of motion for capital (3) we have

$$
K^{G}=\frac{\Delta_{G}}{\delta_{K^{G}}} \bar{Y}(H),
$$

and using (18) to substitute for output we have

$$
K^{G}=\frac{\Delta_{G}}{\delta_{K^{G}}} \frac{1}{\Delta E}\left[\frac{\left(\frac{H^{1-\gamma_{2}}}{B}\right)^{\eta_{1} / \gamma_{1}}-\left(a N^{c} H\right)^{\eta_{1}}}{\chi_{1}}\right]^{\frac{1}{\eta_{1}}}
$$

We use (20) in the production function for the public good (2) and get

$\bar{G}(H) \equiv G=Z\left[\left(\frac{\Delta_{G}}{\delta_{K^{G}}} \frac{1}{\Delta E}\left[\frac{\left(\frac{H^{1-\gamma_{2}}}{B}\right)^{\eta_{1} / \gamma_{1}}-\left(a N^{c} H\right)^{\eta_{1}}}{\chi_{1}}\right]^{\frac{1}{\eta_{1}}}+\chi_{2}\left[(1-a) N^{u} H\right]^{\eta_{2}}\right]^{1 / \eta_{2}}\right.$

that expresses the output of the public good $G$ as a function of human capital $H$. Then the steady state output is given by

$$
Y=A[\bar{G}(H)]^{\alpha_{1}}[\bar{K}(H, R)]^{\alpha_{2}}\left[\bar{H}\left(1-N^{u}\right)\right]^{\alpha_{3}} .
$$

The six steady state variables $H, K^{g}, G, K, Y, R$ are determined by the six equations (17), (18), (20), (21), (19), (22).

\subsection{The Case of Government Debt with Cobb-Douglas within Period $(\rho=0)$ Utility Function}

Introducing government bonds does not change the household's first order conditions. However, when aggregating over all households we have to include bonds as the additional asset, so that total bonds and capital is

$$
\begin{aligned}
K+B & =N^{u} i^{u}+\left(1-N^{u}\right) i^{r} \\
& =\frac{Y}{1+\mathcal{C} R}\left\{\begin{array}{c}
\left(\frac{N^{u}}{1-N^{u}}\right) \frac{\xi \alpha_{3}}{1+\tau_{t}^{s s f}}\left[\left(1-\tau_{L}^{s s u}-\tau_{L}^{u}\right)-\mathcal{C} \Psi\right] \\
+\left(1-\tau_{L}^{s s r}-\tau_{L}^{r}\right) \frac{\alpha_{3}}{1+\tau_{t}^{s s r f}}-\mathcal{C} \Delta_{T^{r}}
\end{array}\right\} .
\end{aligned}
$$

We can express $K=\alpha_{2}\left(1-\tau_{K}\right) \frac{Y}{R}$ and $B=\Delta_{B} Y$ where $\Delta_{B}$ is the debt level set exogenously by the government. Making the substitutions we get

$$
\Delta_{B}+\alpha_{2}\left(1-\tau_{K}\right) \frac{1}{R}=\frac{1}{1+\mathcal{C} R}\left\{\begin{array}{c}
\frac{N^{u}}{1-N^{u}} \xi \frac{\alpha_{3}}{1+\tau_{t}^{s s r f}}\left[\left(1-\tau_{L}^{s s u}-\tau_{L}^{u}\right)-\mathcal{C} \Psi\right] \\
+\left(1-\tau_{L}^{s s r}-\tau_{L}^{r}\right) \frac{\alpha_{3}}{1+\tau_{t}^{s s r f}}-\mathcal{C} \Delta_{T^{r}}
\end{array}\right\}
$$


where we know that $\mathcal{C}=[\beta R]^{\frac{1}{\theta(1-\sigma)-1}}$ is a function of steady state $R$. Simplifying and assuming that $\tau_{L}^{u}=\tau_{L}^{r}$ we get

$$
\Delta_{B}+\alpha_{2}\left(1-\tau_{K}\right) \frac{1}{R}=\frac{1}{1+\mathcal{C} R}\left\{\begin{array}{c}
\frac{\alpha_{3}}{1+\tau_{t}^{s s r f}}\left(1-\tau_{L}^{s s u}-\tau_{L}^{u}\right)\left(1+\frac{N^{u}}{1-N^{u}} \xi\right) \\
-\left(\frac{N^{u}}{1-N^{u}} \xi \frac{\alpha_{3}}{1+\tau_{t}^{s s r f}} \Psi+\Delta_{T^{r}}\right) \mathcal{C}
\end{array}\right\}
$$

Next we use the government budget constraint in the steady state

$$
\begin{gathered}
\frac{\alpha_{3}}{1+\tau^{s s r f}} \tau_{L}\left(\xi \frac{N^{u}}{1-N^{u}}+1\right)+\tau_{K} \alpha_{2} \\
=(R-1) \Delta_{B}+\left[\Delta_{E}+\Delta_{G}\right]+\xi \frac{\alpha_{3}}{1+\tau^{s s r f}} \frac{N^{u}}{1-N^{u}}+\Delta_{T^{r}} \\
+\Psi \xi \frac{\alpha_{3}}{1+\tau^{s s r f}} \frac{N^{u}}{1-N^{u}}-\frac{\alpha_{3}}{1+\tau^{s s r f}}\left(\xi \frac{N^{u}}{1-N^{u}} \tau_{L}^{s s u}+\tau_{L}^{s s r}+\tau_{L}^{s s f}\right) .
\end{gathered}
$$

Equations (23) and (24) determine the steady state interest rate $R$ and one endogenized government variable. This government variable can either be a tax rate or one of the four government policy variables $\left(\Delta_{B}, \Delta_{E}, \Delta_{G}, \Delta_{T}\right)$ that can adjust to satisfy the government budget constraint. We can now calculate the remaining six steady state variables $H, K^{g}, G, K, Y$ using expressions (18), (20), (21), (19), (22).

\section{Data and Calibration}

In this section we calibrate the model to the economy of Brazil. Table 1 reports the preference and technology parameters. The preference parameters are perhaps non controversial. The discount factor is a standard one year estimate. Since one period is roughly 30 years long, we scale the discount factor accordingly. The parameter $\theta=0.95$, so that the weight consumers place in their utility function on publicly provided goods is small.

Note that for the parameters for the consumption goods technology we are imposing constant returns to scale in the two private factors. Note also that capital's share of 0.5 is large relative to the estimates reported in Gollin (2002), but this relatively large parameter value is consistent with estimates for Brazil in Elias (1992) and with values used by Barro and Sala-i-Martin (2004).

The value for the elasticity of output with respect to infrastructure capital, $\alpha_{1}$ lies between estimates by Holtz-Eakin (1994) and Ai and Cassou (1995). For the parameter $\eta_{2}$ in the government technology we use a value of 0.5 as a benchmark, but we will use other parameter values in our sensitivity analysis. We are not aware of any estimates of $\eta_{2}$. We set the parameter $\chi_{2}$, which measures the labor intensity of this technology, equal to unity.

We use a value of 0.1 for the learning elasticity with respect to public expenditure. This is consistent with an estimate by Card and Krueger (1992) and values used by Fernandez and Rogerson (1996) and by Rangazas (2000). We are also not aware of any estimates of $\eta_{1}$. We thus use $\eta_{1}=0.5$ as a benchmark and perform sensitivity analysis 
using a variety of values for $\eta_{1}$. The productivity parameters $A, B, Z$ are chosen so that for the benchmark, output is equal to 100 .

The government budget constraint becomes

$$
\begin{aligned}
& \text { tax revenue excl. ear market social sec. contribution rates }(27 \%) \\
& \overbrace{\Delta_{B, t} Y_{t}}^{B_{t+1} \text { new debt }}+\overbrace{\left[\frac{\alpha_{3}}{1+\tau_{t}^{s s r f}}\left(\tau_{L, t}^{u} \xi \frac{N^{c}}{1-N_{t}^{u}}+\tau_{L, t}^{r}\right)+\tau_{K, t} \alpha_{2}\right]}^{Y_{t}} \\
& =\overbrace{R_{t} \Delta_{B, t-1} Y_{t-1}}^{R_{t} B_{t} \text { debt service }}+\overbrace{\left[\Delta_{E, t}+\Delta_{G, t}\right]}^{\text {Education }+ \text { Investments }}+\overbrace{\xi \frac{\alpha_{3}}{1+\tau_{t}^{s s r f}} \frac{N_{t}^{u}}{1-N_{t}^{u}}}^{\text {public wages }(10 \%)} Y_{t}
\end{aligned}
$$

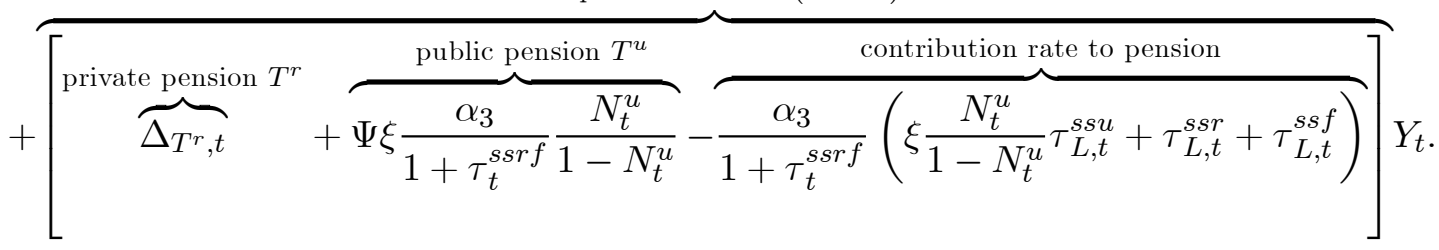

Table 2 reports the specific public policy parameters we use for the calibration exercise. The top panel in table 2 contains data on government expenditures, the second panel contains data on tax rates, while the third panel contains data on the relative size of the public and private labor force.

We set public expenditures on education exclusive of teacher salaries equal to $1 \%$ of GDP. According to The economist (Feb. 20, 2003), total public education expenditure in Brazil in 1999 was $5.1 \%$ of GDP. We subtract $25 \%$ which is spent on tertiary education, since only $2 \%$ of all students attend college, leaving us with $3.825 \%$ of GDP. We assume that about $75 \%$ of that is spent on salaries of teachers and administrators, leaving about $1 \%$ of GDP for buildings, computers, textbooks, etc.

According to (Calderon, Easterly and Serven, 2003, table 4.1), investment in infrastructure is about $1 \%$ of GDP. Wages to current civil servants amount to about $3.5 \%$ of GDP. According to the Ministerio de Previdencia e Assistencia Social of Brazil transfers to the old in the private sector amount to $6.6 \%$ of GDP, while public sector pensions amount to about $5 \%$ of GDP (see Souza et al. (2004)).

In our model public sector wages are higher than private sector wages by a factor $\xi$. We do not have data on $\xi$ and use $\xi=1.28$. This may be conservative.

In order to model integrality, we need a measure of wages in the last years of one's career relative to wages averaged over the entire career. We set this number $\Psi=1.5$.

Basically all of our data on tax rates come from Souza et al. (2004). The social security tax rate levied from both public sector workers is $11 \%$ of wage income. In the private sector employers add $10 \%$ of the wage bill to the pension fund. ${ }^{6}$

The labor income tax rate for both types of employees net of social security contributions is $9 \%$. The capital tax rate is $9 \%$ resulting in tax revenue as a fraction of GDP of

\footnotetext{
${ }^{6}$ Since our model does not account for all government expenditure, our tax rate on employers is lower than the $20 \%$ reported by (Souza et al., 2004, p. 5).
} 
$27 \%$ excluding social security contribution rates. Once we include debt financing to the government budget constraint, the capital tax rate is considerably higher and reaches $53 \%$.

According to the Social Security Ministry of Brazil in 2002 there are about 5.2 million civil servants in Brazil; this constitutes $6 \%$ out of a labor force of about 85 million. According to the Global Education Database, there are approximately 2.17 million teachers in Brazil. Thus we set $a=42 \%$.

\section{Policy Experiments}

Initially we assume that the government budget is balanced every period, that is the government does not issue debt. For the following policy experiments we set $\tau_{L, t}^{u}=\tau_{L, t}^{r}$, so that the government budget constraint reduces to

$$
\begin{gathered}
\frac{\alpha_{3}}{1+\tau_{t}^{s s r f}} \tau_{L, t}\left(\xi \frac{N_{t}^{u}}{1-N_{t}^{u}}+1\right)+\tau_{K, t} \alpha_{2} \\
=\Delta_{E, t}+\Delta_{G, t}+\xi \frac{\alpha_{3}}{1+\tau_{t}^{s s f}} \frac{N_{t}^{u}}{1-N_{t}^{u}}+\Delta_{T^{r}, t}+\Psi \xi \frac{\alpha_{3}}{1+\tau_{t}^{s s r f}} \frac{N_{t}^{u}}{1-N_{t}^{u}}-\frac{\alpha_{3}}{1+\tau_{t}^{s s f f}}\left(\xi \frac{N_{t}^{u}}{1-N_{t}^{u}} \tau_{L, t}^{s s u}+\tau_{L, t}^{s s r}+\tau_{L, t}^{s s f}\right) .
\end{gathered}
$$

\subsection{Public Pensions $(\Psi)$ vs. Private Pensions $\left(\Delta_{T^{r}}\right)$}

In the first policy experiment we use the extra revenue from making public sector pensions less generous to make private sector social security payments more generous. This policy experiment is motivated by the attempts of Constitutional Amendment 40 to provide for more equity between the public and private sector pension system. (see (Souza et al., 2004 , p. 1)). We perform this reallocation in such a way that government's share of GDP remains constant. The results from this experiment are illustrated in figure 1.

The effect of shifting public funds from public pensions to private pensions on steady state income is nil. This result is not that surprising since this policy is just a reshuffling of expenditures in the government budget constraint and public and private sector have the same propensity to save.

The dashed line indicates the direct effect of making public sector pensions less generous without using the extra funds on the private pensions. This direct effect of reducing generosity of public pensions on output, total saving and savings by sector is positive.

First, public sector workers have a bigger incentive to save as their pensions are reduced. The increase in savings by civil servants causes the interest rate to decrease which causes private sector savings to fall and aggregate output to increase which, through the wage rate, causes private sector savings to rise. The second effect dominates the first effect.

\subsection{Public Pensions $(\Phi)$ vs. Education $\left(\Delta_{E}\right)$}

In the second experiment we use the extra government revenue from making public pensions less generous to finance extra public education expenditures. According to figure 2, this policy reform raises steady state income. There are two effects, a direct 
effect on savings and an opportunity cost effect of being able to use the released public funds for some other purpose, in this case more material inputs into education. The intuition is clear: Decreasing $\Psi$ increases public sector savings, which in turn increases steady state capital and output. This direct effect indicated by the dashed line is small. Using the extra revenue to fund higher education increases the steady state level of human capital, hence the rate of return on saving, the capital stock and steady state GDP. This effect is large. Reducing $\Psi$ from 1.5 to 1.25 increases steady state GDP by more than $10 \%$.

Of course the size of these effects depends upon the technology parameters, especially on the size of $\gamma_{1}$, the elasticity of learning output with respect to public expenditures. We summarize the results of this sensitivity analysis in table 3 where we allow $\gamma_{1}$ to vary from 0.05 to 0.15 . The effects on steady state income from reducing $\Psi$ from 1.5 to 1.25 vary from almost $6 \%$ to over $18 \%$.

In table 4 we illustrate how shifting public funds from public sector pensions to education depends upon $\eta_{1}$, the (inverse of the) elasticity of substitution in the education production function. We see from table 4 that our results are relatively sensitive to sizeable changes in $\eta_{1}$. As $\eta_{1}$ varies from 0.00 to 1 the effect of reducing $\Psi$ from 1.50 to 1.25 varies between $3.87 \%$ and $15.95 \%$.

\subsection{Public Pensions $(\Psi)$ vs. Public Investment $\left(\Delta_{G}\right)$}

In the third experiment the extra revenue from cutting public sector pensions is used to invest in public sector capital. The results are illustrated in figure 3. Qualitatively these results in figure 3 are the same as those in figure 2. The only difference is quantitative. For the base line parameters the effects from using the freed-up resources for public investment generates larger effects on steady state GDP than using these resources for public education. Reducing $\Psi$ from 1.50 to 1.25 causes GDP to increase by approximately $17 \%$. The corresponding increase when these funds are used for education is "only" $12 \%$.

In table 5 we show how sensitive the results are with respect to changes in $\alpha_{1}$, the elasticity of output with respect to public capital. We allow $\alpha_{1}$ to vary from 0.05 to 0.15 . For this range of parameter values reducing $\Psi$ from 1.5 to 1.25 increases steady state output by almost $8 \%$ and about $30 \%$. Thus, for realistic parameter values the effects of reallocating funds to public investment can be enormous.

In table 6 we again compare how shifting public funds from public sector pensions into public sector capital depending on $\eta_{2}$, the elasticity of substitution in the public production function. The effects on steady state income of using the extra revenue from public sector pensions for investment in infrastructure are quite sensitive to changes in $\eta_{2}$. As $\eta_{2}$ declines, the effect on output declines as well. If $\eta_{2}=-1$, reducing $\Psi$ from 1.50 to 1.25 increases steady state output by "only" $2 \%$. 


\subsection{Public Pensions ( $\Psi)$ vs. Adjustments in Labor Taxes $\left(\tau_{L}\right)$ and Capital Taxes $\left(\tau_{K}\right)$}

The fourth and fifth experiment describes the effects of cutting public sector pensions and subsequent decreases in either labor taxes $\tau_{L}$ or capital taxes $\tau_{K}$. Figures 4 and 5 summarize the results. Decreasing the labor tax generates much larger effects on steady state income than decreasing the capital tax.

\subsection{Comparison of Policies}

The question arises whether the extra revenue from decreasing public sector pensions is more beneficially allocated to public capital investment or to public education. The answer to this question naturally depends upon the productivity parameters $\alpha_{1}, \gamma_{1}, \eta_{1}$ and $\eta_{2}$.

Tables 7 and 8 show the relative steady state output effect from using the extra revenue for education rather than infrastructure. In table 7 negative numbers indicate that using the freed-up resources for infrastructure investment generates higher effects on GDP. It is interesting that basically for the whole range of $\gamma_{1} \in[0.05,0.15]$ investment in public capital dominates investment in education. The same holds true for the range of $\alpha_{1} \in[0.05,0.15]$ in table 8 . This result obtains most likely because in our calibrations as in the data public investment in infrastructure is low (1\% of GDP) relative to the optimal level.

Once we change the underlying elasticity parameter $\eta_{2}$ to -0.25 we get a range for $\gamma_{1}$ and $\alpha_{1}$ where investment in education will dominate investment in public capital. This is illustrated in tables 9 and 10 . This is due to the fact that a negative $\eta_{2}$ changes the relation of public sector investments and investments in education from being substitutes to becoming complements. Increases in $\gamma_{1}$ will now not only increase output through the direct channel of increases in human capital (via increased productivity of educational expenses) but also through the indirect channel of increases in output of the public good. The complementarity enhances the effectiveness of public education versus investments into the public capital.

\subsection{Government Debt}

We now allow for government debt and again equate public and private wage taxes. We then have the following government budget constraint:

$$
\begin{gathered}
\frac{\alpha_{3}}{1+\tau^{s s r f}} \tau_{L}\left(\xi \frac{N^{u}}{1-N^{u}}+1\right)+\tau_{K} \alpha_{2} \\
=(R-1) \Delta_{B}+\Delta_{E}+\Delta_{G}+\xi \frac{\alpha_{3}}{1+\tau^{s s r f}} \frac{N^{u}}{1-N^{u}}+\Delta_{T^{r}} \\
+\Psi \xi \frac{\alpha_{3}}{1+\tau^{s s r f}} \frac{N^{u}}{1-N^{u}}-\frac{\alpha_{3}}{1+\tau^{s s r f}}\left(\xi \frac{N^{u}}{1-N^{u}} \tau_{L}^{s s u}+\tau_{L}^{s s r}+\tau_{L}^{s s f}\right) .
\end{gathered}
$$

We interpret $(R-1) \Delta_{B}$ as the interest level on outstanding debt (government bonds) that the government has to service in the steady state. 


\subsubsection{Experiment 1: $\Delta_{B}$ adjusts}

We perform the following policy experiment: We decrease the generosity of the public sector pensions, i.e. $\Psi$ goes down. At the same time we let $\Delta_{B}$ adjust to clear the government budget constraint holding all other government choice variables fixed. Then we see directly from the government budget constraint that $\Psi$ and $\Delta_{B}$ are negatively related.

When government cuts public pensions it has more funds available to service the interest payments of a higher debt level. With lower payments into public pensions, the government can sustain a higher debt level in the steady state.

On the other hand if government would increase the generosity of public pensions, its steady state expenditure goes up. Therefore, government cannot afford high interest payments on outstanding debt and it therefore has to reduce the amount of debt (compare figure 6).

\subsubsection{Experiment 2: $\tau^{L}$ or $\tau^{K}$ adjusts}

In this policy experiment we decrease the generosity of public pensions $\Psi$ and let the labor tax $\tau_{L}$ or the capital tax rate $\tau_{K}$ adjust. Figure 7 and figure 8 report the respective effects. When $\Psi$ drops from 1.5 to 1.25 , and $\tau_{L}$ adjusts downwards, then output increases by $40 \%$. This effect is very large. There are several effects at work here; all effects go in the same direction.

First, there is an income effect due to the lower labor tax rate on the young. Since the young are the only savers in the model, increasing their after tax income increases savings, capital accumulation and steady state income. This effect is reinforced by a simultaneous drop in the real interest rate, which lowers debt service and allows a further reduction in the labor income tax rate. This additional reduction in the income tax rate (which is much smaller in the case when the government does not issue debt as in figure 4) further stimulates capital accumulation and increases steady state income. Notice in figure 7 that for large enough reductions in $\Psi$ the labor tax rate actually becomes negative, i.e. saving is subsidized. There is also the increased savings of civil servants due to the reduction in their expected future pension payments. These effects together cause a massive effect on steady state output. ${ }^{7}$

An adjustment of $\tau_{K}$ has a minor effect on output of roughly $2 \%$ when $\Psi$ declines from 1.5 to 1.25 (see figure 8 ).

\footnotetext{
${ }^{7}$ In addition to the steady state equilibrium depicted in figure 7 there is a second type of steady state equilibrium in which a decrease of $\Psi$ causes the interest rate $R$ and the labor tax rate $\tau_{L}$ to rise. An increase in $R$ is then consistent with lower savings, lower investment and hence higher marginal product of capital such that the government budget constraint is still satisfied. All these together result in a decrease of steady state output.
} 


\section{Conclusion}

In this paper we have used an overlapping generations model to assess the effects of public pension reform on capital accumulation. We have calibrated the model to Brazil. We found $(i)$ The direct effects of pension reform through savings of civil servants are small. (ii) Shifting government funds from public to private sector pensions leaves steady state GDP unaffected. (iii) The indirect effects of reduction of public pensions by freeing resources for public education or investment in public capital are large.

In this paper we have concentrated on one particular channel of how public sector pension reform might influence capital accumulation. Other channels might be: $(i)$ The generosity of public sector pensions influences workers' retirement decisions, which in turn has an effect on GDP. ( $i i)$ The generosity of public sector pensions relative to pensions in the private sector will influence how workers will be allocated across both sectors, which in turn will influence GDP. This would require the introduction of heterogenous agents who make idiosyncratic investment choices into their human capital. This extended framework would allow us to investigate changes in the quality of the public sector labor force, given a specific worker compensation package (wages plus pension plan).

In our model the publicly produced service was made available to all firms and households at a zero price. While this might be a useful assumption for the provision of infrastructure like roads and highways, it clearly does not cover all relevant cases. When governments produce goods like telecommunication services or electricity, they typically charge for these goods/services. Prices charged need not bear any particular relationship to marginal or average costs. This will impact the government budget constraint.

Finally, we restricted our analysis on steady state equilibria. A deeper analysis of policy reform will require emphasis on transition paths from one policy regime to another. We leave these issues for future research.

\section{References}

Ai, Chunrong and Stephen P. Cassou. 1995. "A Normative Analysis of Public Capital." Applied Economics 27:1201-1209.

Barro, Robert J. 1990. "Government Spending in a Simple Model of Endogenous Growth." Journal of Political Economy 98(5):103-125.

Barro, Robert J. and Xavier Sala-i-Martin. 2004. Economic Growth. second ed. Cambridge: The MIT Press.

Benabou, Roland. 1996. "Heterogeneity, Stratification, and Growth: Macroeconomic Implications of Community Structure and School Finance." The American Economic Review 86(3):584-609.

Blankenau, William F. and Nicole B. Simpson. 2004. "Public Education Expenditures and Growth." Journal of Development Economics 73:583-605. 
Bonturi, Marcos. 2002. "The Brazilian Pension System: Recent Reforms and Challenges Ahead." OECD Economics Department Working Paper No. 340.

Calderon, Cesar, William Easterly and Luis Serven. 2003. Latin America's Infrastructure in the Era of Macroeconomic Crisis. Washington, D.C.: The World Bank.

Card, David and Alan B. Krueger. 1992. "Does School Quality Matter? Returns to Education and the Characteristics of Public Schools in the United States." Journal of Political Economy 100:1-40.

Cassou, Steven P. and Kevin J. Lansing. 1998. "Optimal Fiscal Policy, Public Capital, and the Productivity Slowdown." Journal of Economics Dynamics and Control 22(6):911-935.

Elias, V. 1992. Sources of Growth: A Study of Seven Latin American Economies. ICS Press, San Francisco.

Fernandez, Raquel and Richard Rogerson. 1996. "Income Distribution, Communities and the Quality of Public Education." Quarterly Journal of Economics 111:135-164.

Fernandez, Raquel and Richard Rogerson. 1998. "Public Education and Income Distribution: A Dynamic Quantitative Evaluation of Education-Finance Reform." American Economic Review 88(4):813-33.

Glomm, Gerhard and B. Ravikumar. 1994. "Public Investment in Infrastructure in a Simple Growth Model." Journal of Economic Dynamics and Control 18(6):1173-1187.

Gollin, Douglas. 2002. "Getting Income Shares Right." Journal of Political Economy 110(2):458-474.

Holtz-Eakin, Douglas. 1994. "Public Sector Capital and the Productivity Puzzle." Review of Economics and Statistics 76(1):12-21.

Loury, Glenn C. 1981. "Intergenerational Transfers and the Distribution of Earnings." Econometrica 49(4):843-867.

Rangazas, Peter. 2000. "Schooling and Economic Growth: A King-Rebelo Experiment with Human Capital." Journal of Monetary Economics 46:346-416.

Souza, Andre Portela, Helio Zylberstajn, Luis Eduardo Afonso and Priscilla Matia Flori. 2004. "Fiscal Impacts of Social Securty Reform in Brazil." Working Paper.

Turnovsky, Stephen J. and Walther H. Fisher. 1995. "The Composition of Government Expenditure and Its Consequences for Macroeconomic Performance." Journal of Economic Dynamics and Control 19(4):747-786. 


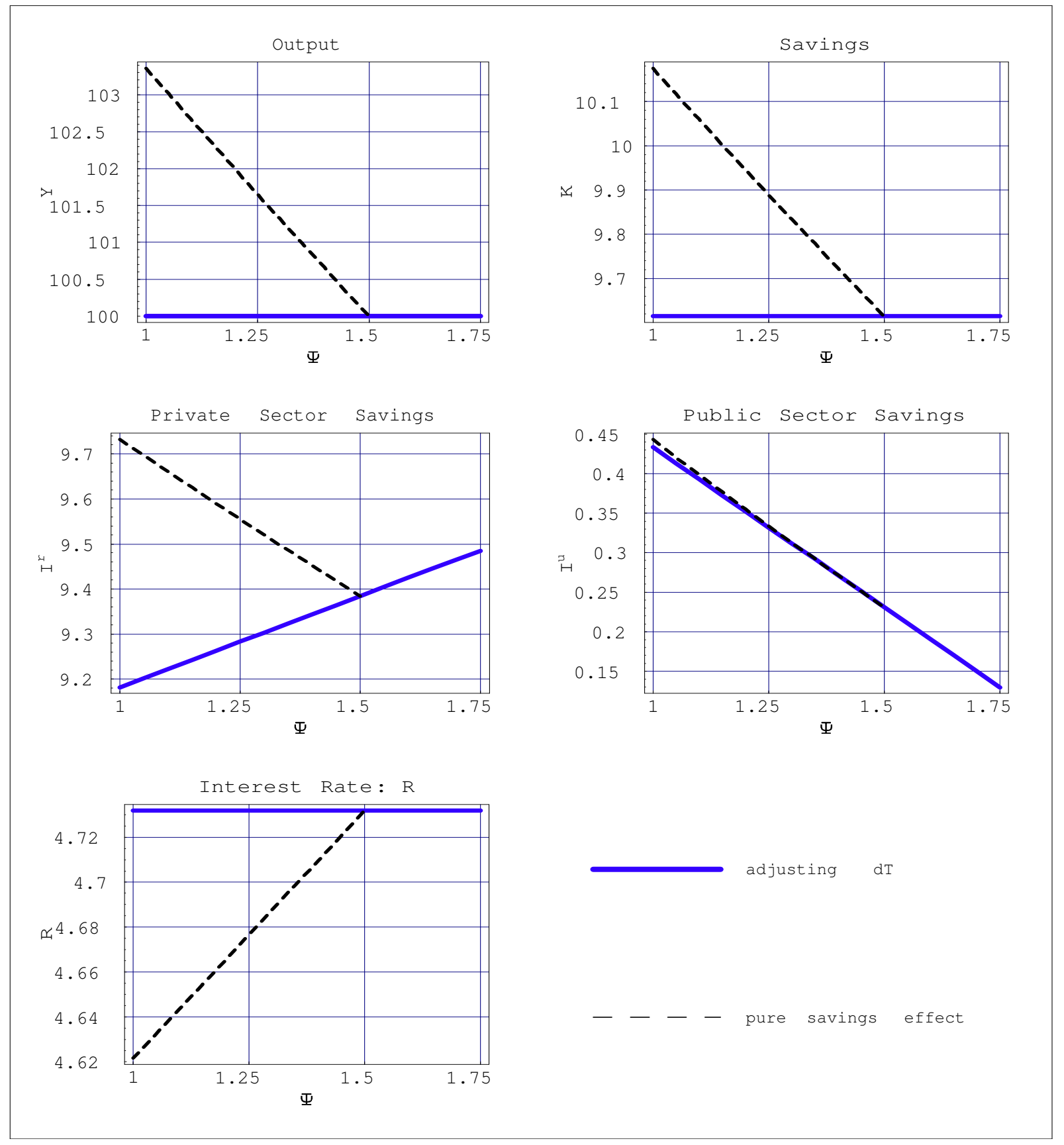

Figure 1: Effect of decreasing public sector pensions $\Psi$ and increasing private sector pensions $\Delta_{T}$ 


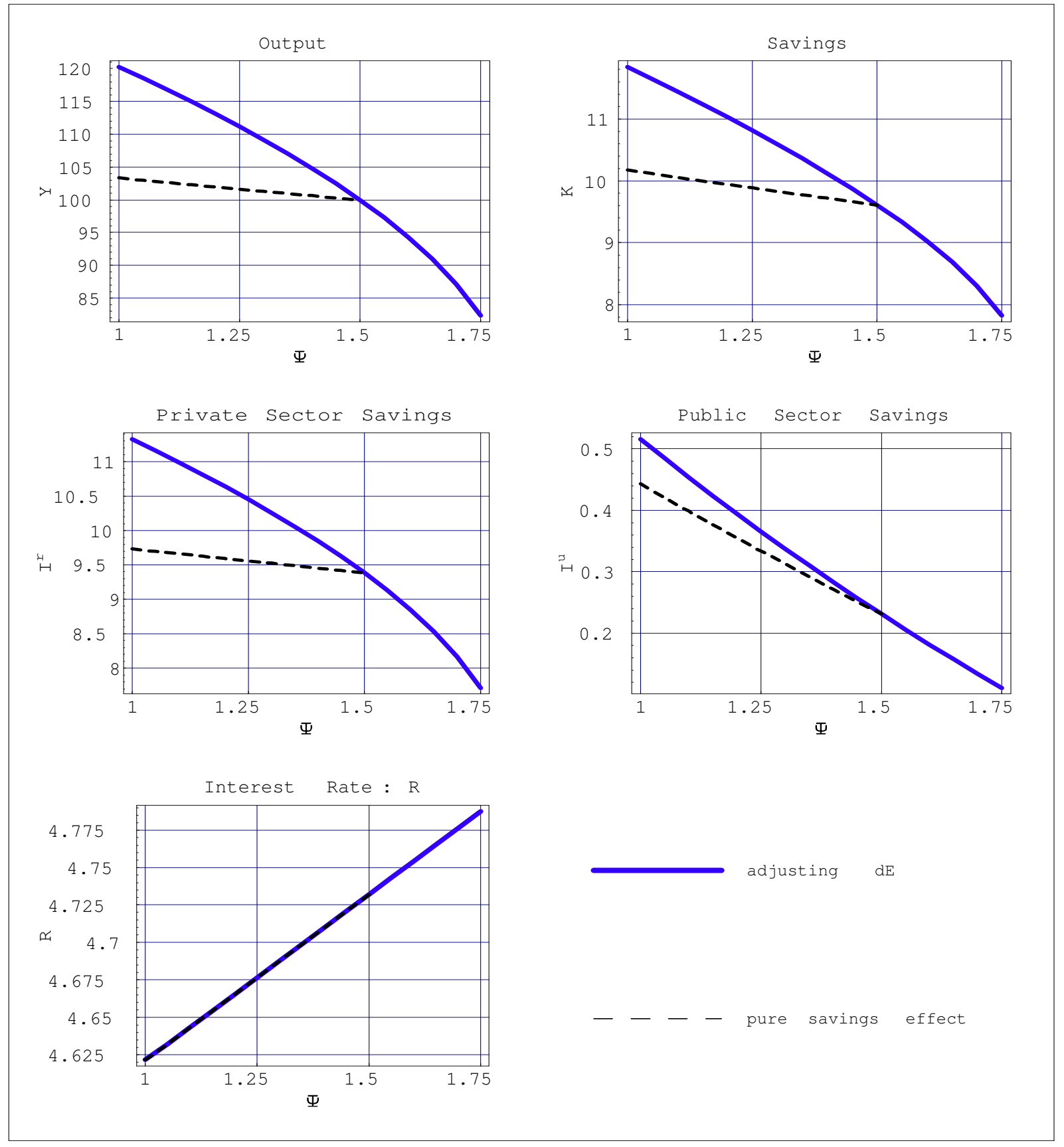

Figure 2: Effect of decreasing public sector pensions $\Psi$ and increasing public education expenditures $\Delta_{E}$ 


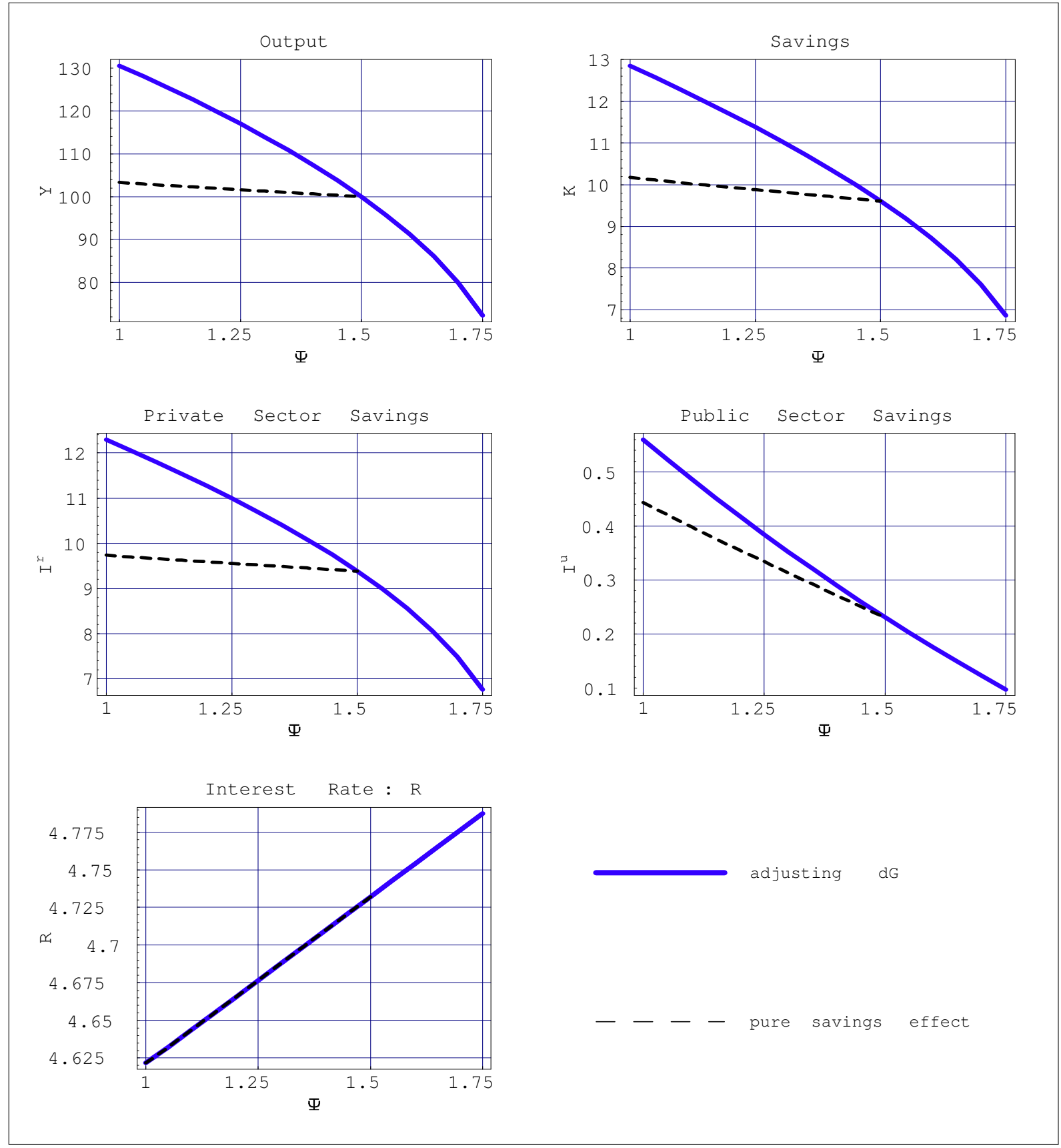

Figure 3: Effect of decreasing public sector pensions $\Psi$ and increasing public capital investments $\Delta_{G}$ 


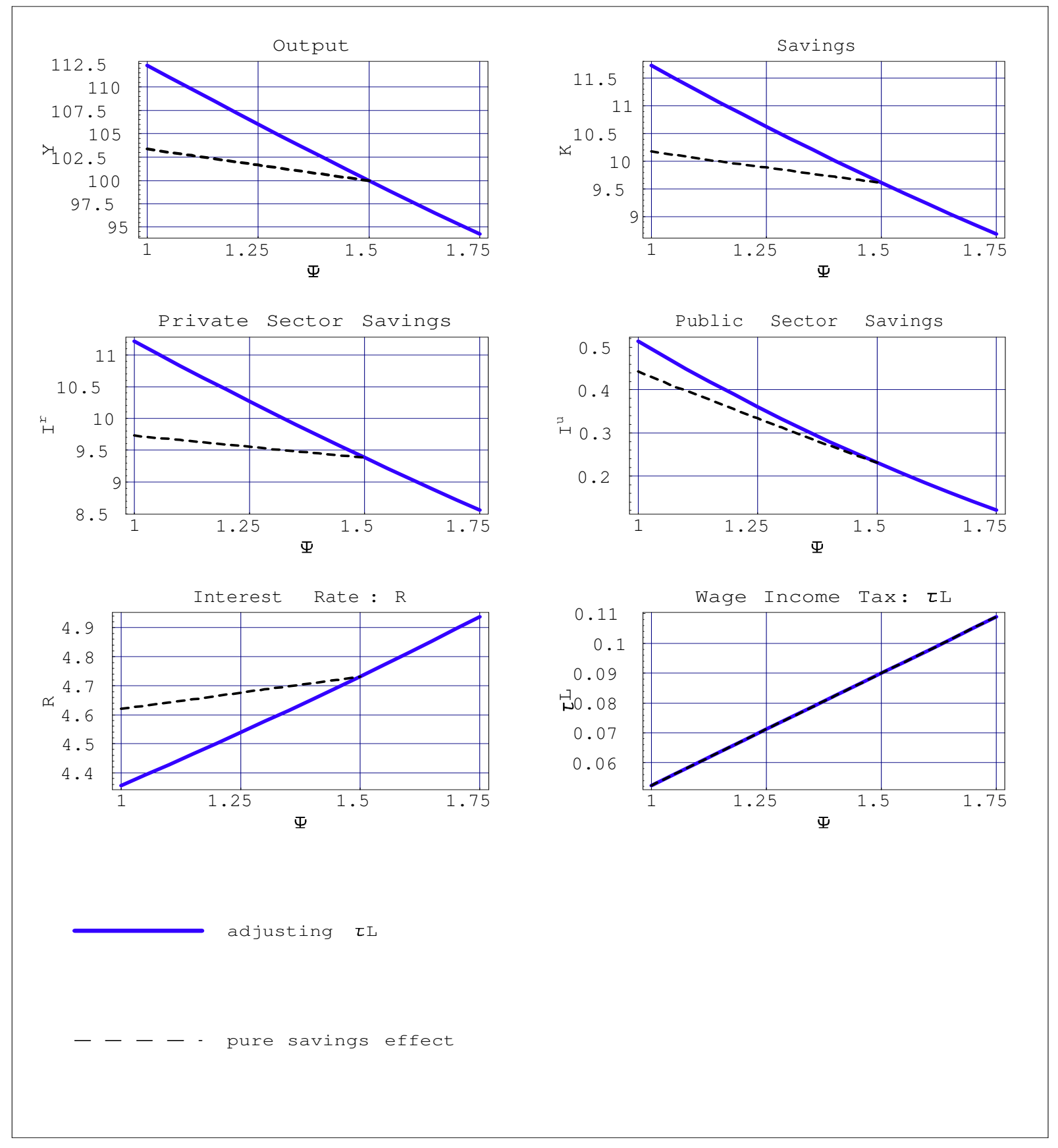

Figure 4: Effect of decreasing public sector pensions $\Psi$ and adjusting labor $\operatorname{tax} \tau_{L}$ 


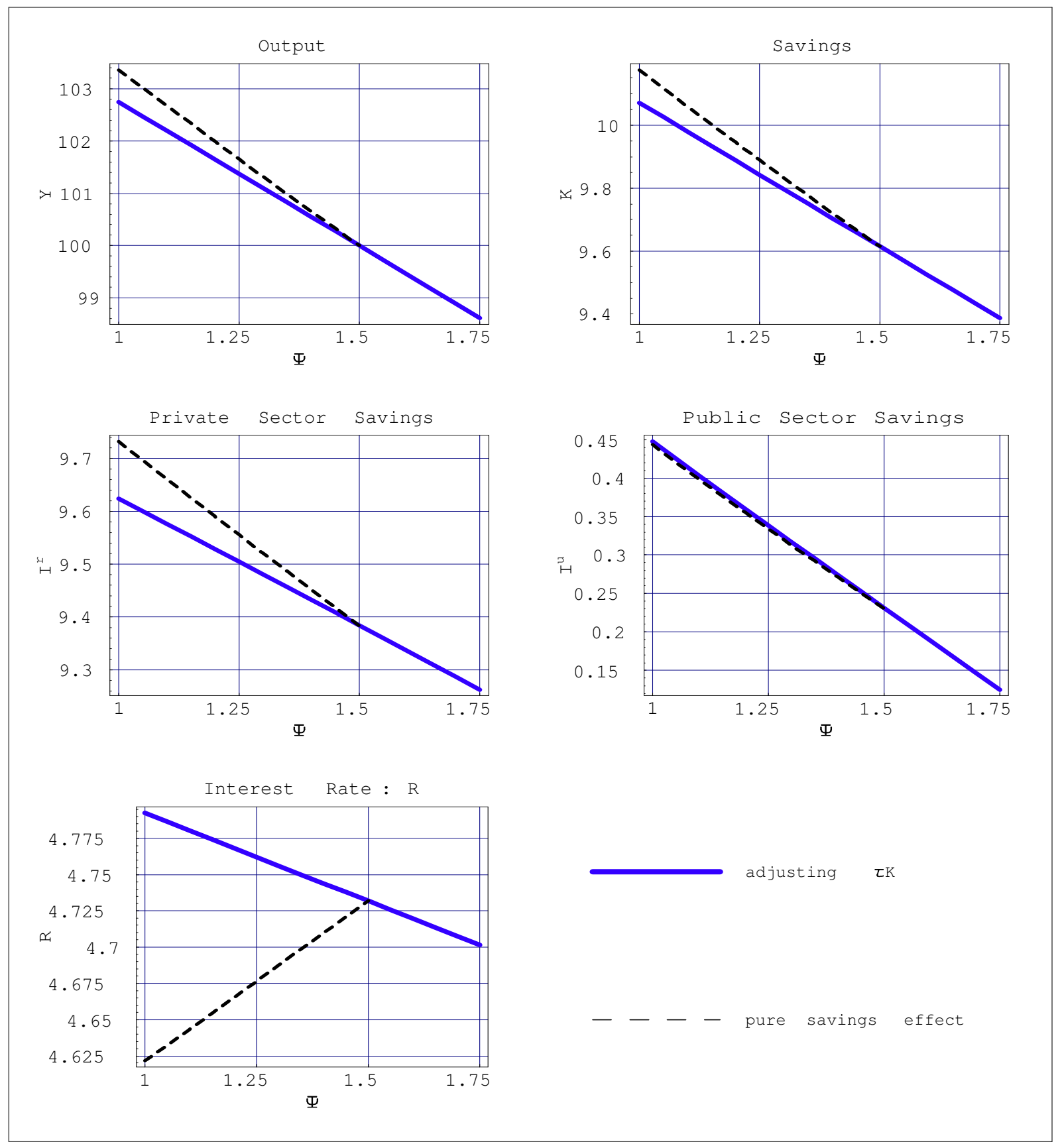

Figure 5: Effect of decreasing public sector pensions $\Psi$ and adjusting capital tax $\tau_{K}$ 


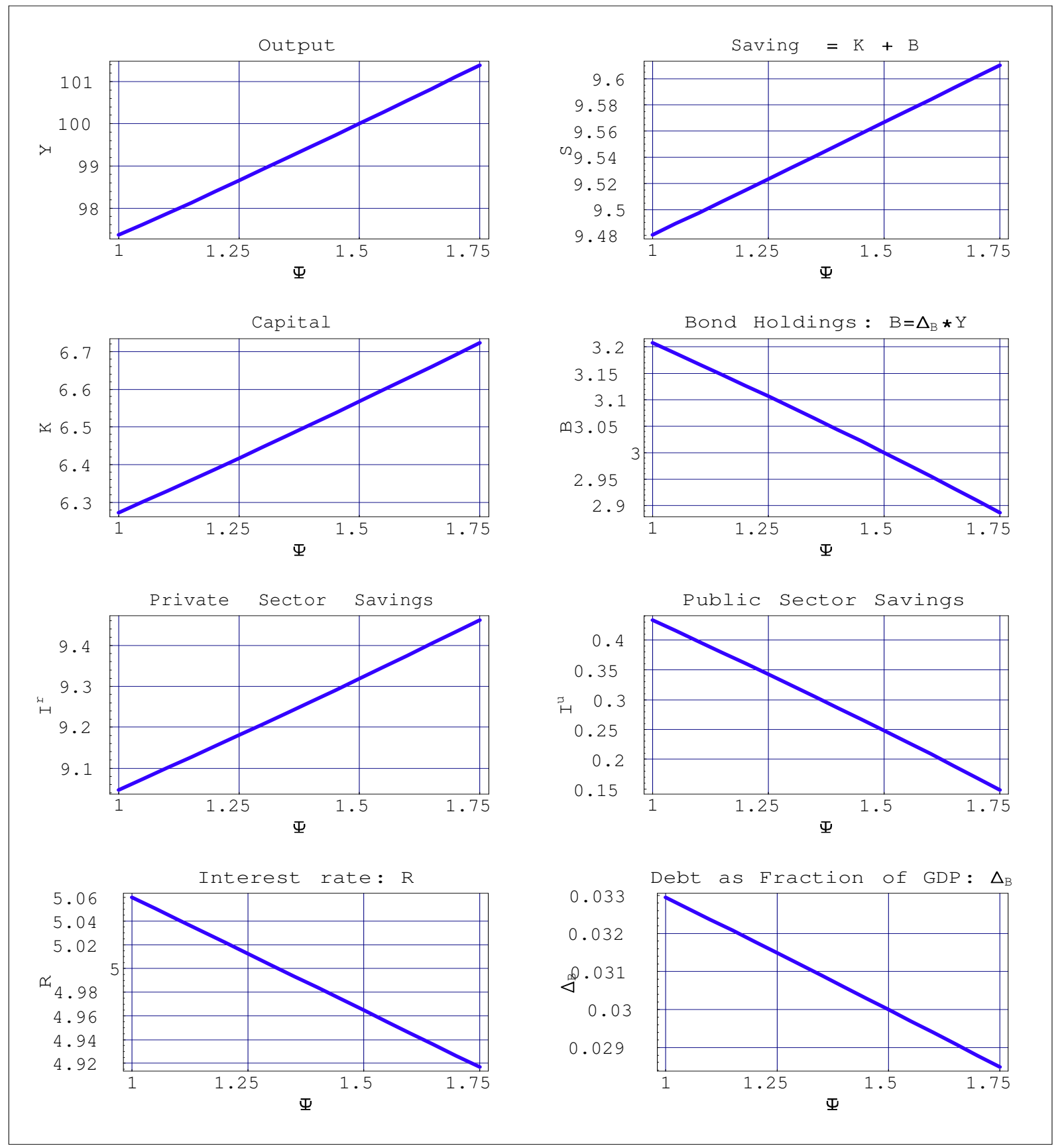

Figure 6: Effect of decreasing public sector pensions $\Psi$ and increasing government debt $\Delta_{B}$ 


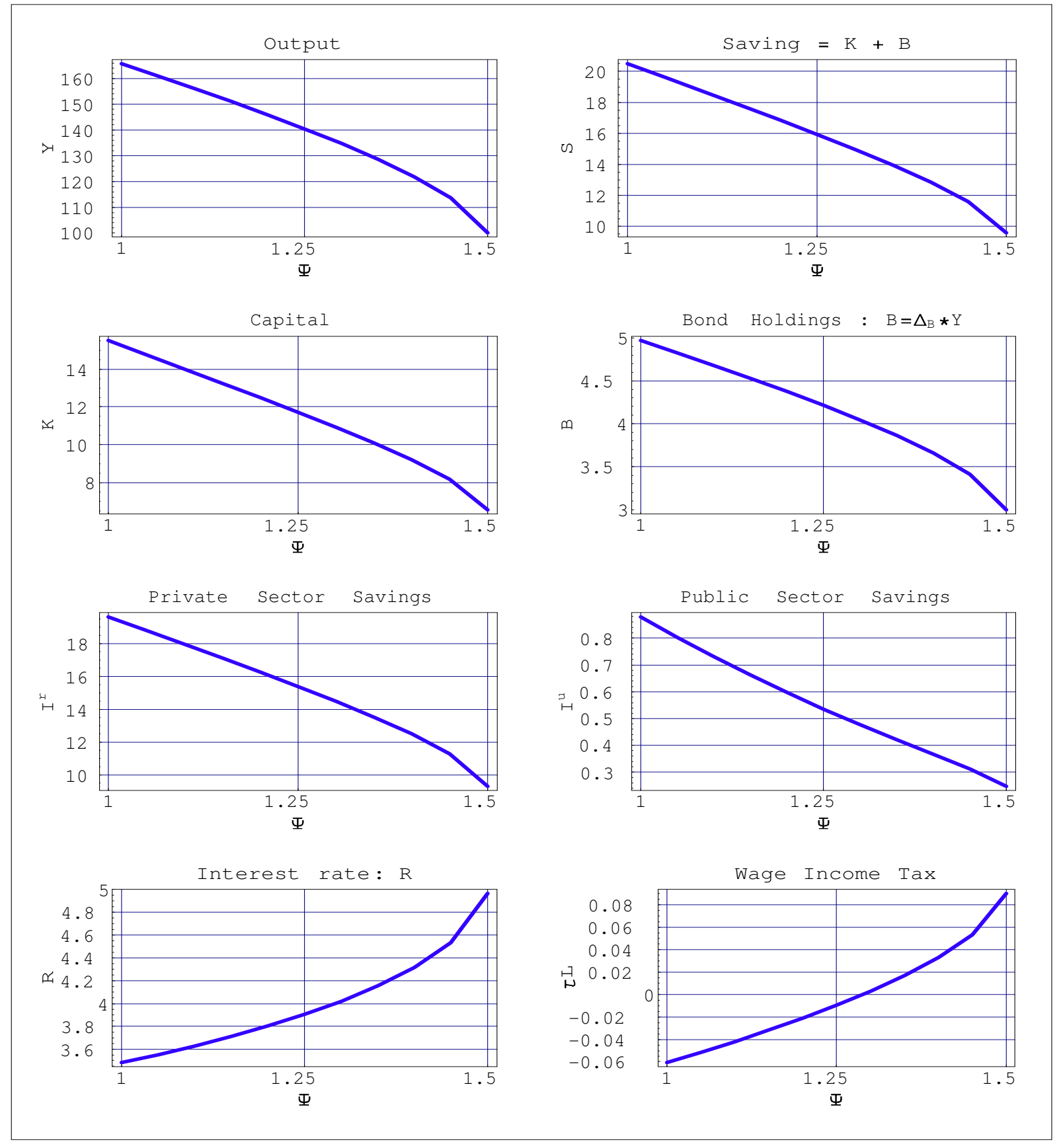

Figure 7: Effect of decreasing public sector pensions $\Psi$ and decreasing labor taxes $\tau_{L}$ 




Figure 8: Effect of decreasing public sector pensions $\Psi$ and adjusting capital taxes $\tau_{K}$ 


\begin{tabular}{ll}
\hline \multicolumn{1}{c}{ Parameters } & \\
\hline \hline Preferences & \\
& $\begin{array}{l}\sigma=1.5 \\
\Theta=0.05 \\
\end{array}$ \\
& $\theta=0.95$ \\
\hline & $\beta=0.995^{30}$ \\
\hline
\end{tabular}

Technology

Consumption Good:

$$
\begin{aligned}
& A=35.26 \\
& \alpha_{1}=0.1 \\
& \alpha_{2}=0.5 \\
& \alpha_{1}=0.4
\end{aligned}
$$

Public Good:

$\begin{array}{ll} & Z=1 \\ & \chi_{2}=1 \\ \text { public capital and labor are substitutes: } & \eta_{2}=0.5 \\ \text { public capital and labor are complements: } & \eta_{2}=-0.25 \\ & \delta_{K^{G}}=0.8\end{array}$

Human Capital:

$$
\begin{aligned}
& B=1 \\
& \chi_{1}=0.2 \\
& \eta_{1}=0.5 \\
& \gamma_{1}=0.1 \\
& \gamma_{2}=0.5
\end{aligned}
$$

Table 1: Preference and Technology Parameters 


\section{Variables}

Policies:

\begin{tabular}{lll}
$\Delta_{E}$ & Public education excl. teacher salaries (in \% of GDP) & $1 \%$ \\
$\Delta_{G}$ & Investment in public good (in \% of GDP) & $1 \%$ \\
$\Delta_{T^{r}}$ & Transfers to old in private sector (in \% of GDP) & $6.6 \%$ \\
$\Delta_{B}$ & Debt level & $3 \%$ \\
$w_{t}^{u} H_{t} N_{t}^{u}$ & wages to current civil servants (in \% of GDP) & $3.5 \%$ \\
$\Psi w_{t}^{u} H_{t} N_{t-1}^{u}$ & pension payments to public sector retirees (in \% of GDP) & $5 \%$ \\
$\xi$ & public wages as a fraction of private wages & 1.28 \\
$\Psi$ & indexation parameter (generosity of public pensions) & 1.5 \\
\hline
\end{tabular}

Taxes:

$\begin{array}{lll}\tau_{L}^{s s u} & \text { social security contribution rate of civil servants } & 11 \% \\ \tau_{L}^{s s r} & \text { social security contribution rate of private sector employees } & 11 \% \\ \tau_{L}^{s s r f} & \text { social security contribution rate of private sector employers } & 10 \% \\ \tau_{K} & \text { capital tax rate (no bonds) } & 9 \% \\ & \text { capital tax rate (with bonds) } & 0.35 \% \\ \tau_{L}^{r} & \text { labor tax rate private sector, net of social security } & 9 \% \\ \tau_{L}^{u} & \text { labor tax rate public sector, net of social security } & 9 \%\end{array}$

Population:

\begin{tabular}{lll}
$N_{t}^{u}$ & fraction of civil servants & $6 \%$ \\
$N^{r}$ & fraction of private sector employees & $94 \%$ \\
$a$ & fraction of teachers in public sector & $42 \%$ \\
\hline \hline
\end{tabular}

Table 2: Government Policy Parameters 


\begin{tabular}{|rrrrrr|}
\hline$\gamma 1$ & \multicolumn{5}{c}{$\Psi$} \\
& & 1.00 & 1.25 & 1.50 & 1.75 \\
0.05 & 110.29 & 105.66 & 100.00 & 91.01 \\
0.06 & 112.04 & 106.64 & 100.00 & 89.37 \\
\hline 0.07 & 113.90 & 107.68 & 100.00 & 87.68 \\
0.08 & 115.88 & 108.77 & 100.00 & 85.95 \\
0.09 & 118.00 & 109.94 & 100.00 & 84.17 \\
0.10 & 120.27 & 111.17 & 100.00 & 82.34 \\
0.11 & 122.69 & 112.49 & 100.00 & 80.46 \\
0.12 & 125.30 & 113.89 & 100.00 & 78.53 \\
0.13 & 128.11 & 115.38 & 100.00 & 76.54 \\
0.14 & 131.15 & 116.98 & 100.00 & 74.50 \\
0.15 & 134.43 & 118.69 & 100.00 & 72.40 \\
\hline
\end{tabular}

Table 3: Change in Output with $\Delta_{E}$ adjusting $\left(\eta_{2}=0.5\right)$

\begin{tabular}{|c|c|c|c|c|}
\hline \multirow[t]{2}{*}{$\eta 1$} & \multicolumn{4}{|c|}{$\Phi$} \\
\hline & 1.00 & 1.25 & 1.50 & 1.75 \\
\hline 0.00 & 107.01 & 103.87 & 100.00 & 93.14 \\
\hline 0.25 & 112.68 & 107.01 & 100.00 & 88.35 \\
\hline 0.50 & 120.27 & 111.17 & 100.00 & 82.34 \\
\hline 0.75 & 125.92 & 114.38 & 100.00 & 77.07 \\
\hline 1.00 & 128.59 & 115.98 & 100.00 & 73.63 \\
\hline
\end{tabular}

Table 4: Change in Output with $\Delta_{E}$ adjusting

\begin{tabular}{|rrrrrr|}
\hline \multicolumn{1}{|l|}{$\boldsymbol{r} 1$} & & \multicolumn{3}{l|}{$\Psi$} \\
& & 1.00 & 1.25 & 1.50 & 1.75 \\
0.05 & 114.09 & 107.94 & 100.00 & 85.81 \\
0.06 & 116.88 & 109.51 & 100.00 & 83.15 \\
0.07 & 119.90 & 111.20 & 100.00 & 80.46 \\
0.08 & 123.16 & 112.99 & 100.00 & 77.75 \\
0.09 & 126.70 & 114.92 & 100.00 & 75.02 \\
0.10 & 130.54 & 116.98 & 100.00 & 72.26 \\
0.11 & 134.73 & 119.20 & 100.00 & 69.49 \\
0.12 & 139.33 & 121.60 & 100.00 & 66.70 \\
0.13 & 144.38 & 124.20 & 100.00 & 63.89 \\
0.14 & 149.96 & 127.02 & 100.00 & 61.08 \\
0.15 & 156.15 & 130.10 & 100.00 & 58.26 \\
\hline
\end{tabular}

Table 5: Change in Output with $\Delta_{G}$ adjusting $\left(\eta_{2}=0.5\right)$ 


\begin{tabular}{|lrrrrr|}
\hline \multicolumn{1}{l|}{$\eta^{2}$} & & \multicolumn{3}{l|}{$\Psi$} \\
$\mathbf{- 1 . 0 0}$ & 103.27 & 101.74 & 100.00 & 96.18 \\
$\mathbf{- 0 . 7 5}$ & 104.08 & 102.27 & 100.00 & 94.39 \\
$\mathbf{- 0 . 5 0}$ & 105.94 & 103.42 & 100.00 & 91.52 \\
$\mathbf{- 0 . 2 5}$ & 109.80 & 105.69 & 100.00 & 87.40 \\
0.00 & 115.60 & 108.87 & 100.00 & 83.11 \\
0.25 & 125.16 & 114.04 & 100.00 & 76.23 \\
0.50 & 130.54 & 116.98 & 100.00 & 72.26 \\
\hline
\end{tabular}

Table 6: Change in Output with $\Delta_{G}$ adjusting

\begin{tabular}{|rrrrrr|}
\hline$\gamma 1$ & \multicolumn{5}{c}{$\Psi$} \\
& & 1.00 & 1.25 & 1.50 & 1.75 \\
0.05 & -22.64 & -12.78 & 0.00 & 21.84 \\
0.06 & -20.07 & -11.31 & 0.00 & 19.25 \\
0.07 & -17.54 & -9.88 & 0.00 & 16.77 \\
0.08 & -15.06 & -8.48 & 0.00 & 14.42 \\
0.09 & -12.64 & -7.12 & 0.00 & 12.18 \\
0.10 & -10.27 & -5.81 & 0.00 & 10.08 \\
0.11 & -7.98 & -4.54 & 0.00 & 8.11 \\
0.12 & -5.76 & -3.33 & 0.00 & 6.28 \\
0.13 & -3.63 & -2.17 & 0.00 & 4.59 \\
0.14 & -1.59 & -1.07 & 0.00 & 3.05 \\
0.15 & 0.36 & -0.04 & 0.00 & 1.66 \\
\hline
\end{tabular}

Table 7: Absolute Difference: $\Delta_{E}-\Delta_{G},\left(\eta_{2}=0.5\right)$

\begin{tabular}{|c|c|c|c|c|}
\hline \multirow[t]{2}{*}{$\alpha 1$} & \multicolumn{4}{|c|}{$\Phi$} \\
\hline & 1.00 & 1.25 & 1.50 & 1.75 \\
\hline 0.05 & 3.13 & 1.61 & 0.00 & -1.30 \\
\hline 0.06 & 0.98 & 0.39 & 0.00 & 0.86 \\
\hline 0.07 & -1.40 & -0.95 & 0.00 & 3.08 \\
\hline 0.08 & -4.04 & -2.42 & 0.00 & 5.35 \\
\hline 0.09 & -6.98 & -4.03 & 0.00 & 7.68 \\
\hline 0.10 & -10.27 & -5.81 & 0.00 & 10.08 \\
\hline 0.11 & -13.97 & -7.77 & 0.00 & 12.54 \\
\hline 0.12 & -18.15 & -9.96 & 0.00 & 15.08 \\
\hline 0.13 & -22.90 & -12.40 & 0.00 & 17.68 \\
\hline 0.14 & -28.30 & -15.13 & 0.00 & 20.36 \\
\hline 0.15 & -34.51 & -18.21 & 0.00 & 23.12 \\
\hline
\end{tabular}

Table 8: Absolute Difference: $\Delta_{E}-\Delta_{G},\left(\eta_{2}=0.5\right)$ 


\begin{tabular}{|rrrrrr|}
\hline$\gamma 1$ & \multicolumn{5}{c}{$\Psi$} \\
& & 1.00 & 1.25 & 1.50 & 1.75 \\
0.05 & -0.33 & -0.30 & 0.00 & 1.88 \\
0.06 & 0.12 & -0.05 & 0.00 & 1.38 \\
0.07 & 0.54 & 0.19 & 0.00 & 0.93 \\
0.08 & 0.93 & 0.42 & 0.00 & 0.51 \\
0.09 & 1.29 & 0.62 & 0.00 & 0.13 \\
0.10 & 1.62 & 0.80 & 0.00 & -0.20 \\
0.11 & 1.91 & 0.97 & 0.00 & -0.50 \\
0.12 & 2.17 & 1.11 & 0.00 & -0.76 \\
0.13 & 2.39 & 1.23 & 0.00 & -0.98 \\
0.14 & 2.58 & 1.34 & 0.00 & -1.17 \\
0.15 & 2.73 & 1.42 & 0.00 & -1.31 \\
\hline
\end{tabular}

Table 9: Absolute Difference: $\Delta_{E}-\Delta_{G},\left(\eta_{2}=-0.25\right)$

\begin{tabular}{|rrrrr|}
\hline \multicolumn{1}{|l|}{$\alpha$} & & \multicolumn{3}{c|}{$\Phi$} \\
& 1.00 & 1.25 & 1.50 & 1.75 \\
0.05 & 5.01 & 2.75 & 0.00 & -3.72 \\
0.06 & 4.14 & 2.25 & 0.00 & -2.75 \\
0.07 & 3.38 & 1.81 & 0.00 & -1.94 \\
0.08 & 2.71 & 1.42 & 0.00 & -1.25 \\
0.09 & 2.12 & 1.09 & 0.00 & -0.68 \\
0.10 & 1.62 & 0.80 & 0.00 & -0.20 \\
0.11 & 1.19 & 0.56 & 0.00 & 0.18 \\
0.12 & 0.82 & 0.36 & 0.00 & 0.48 \\
0.13 & 0.51 & 0.18 & 0.00 & 0.71 \\
0.14 & 0.25 & 0.04 & 0.00 & 0.88 \\
0.15 & 0.04 & -0.07 & 0.00 & 1.01 \\
\hline
\end{tabular}

Table 10: Absolute Difference: $\Delta_{E}-\Delta_{G},\left(\eta_{2}=-0.25\right)$

\begin{tabular}{|rrrrrr|}
\hline \multicolumn{1}{|l}{$r$} & & \multicolumn{3}{l|}{$\Phi$} \\
& 1.00 & 1.25 & 1.50 & 1.75 \\
0.00 & 127.13 & 115.20 & 100.00 & 74.48 \\
0.25 & 128.60 & 115.97 & 100.00 & 73.52 \\
0.50 & 130.54 & 116.98 & 100.00 & 72.26 \\
0.75 & 132.07 & 117.79 & 100.00 & 71.23 \\
1.00 & 132.87 & 118.22 & 100.00 & 70.64 \\
\hline
\end{tabular}

Table 11: Change in Output with $\Delta_{G}$ adjusting 


\section{CESifo Working Paper Series}

(for full list see www.cesifo-group.de)

1473 Kai A. Konrad, Silent Interests and All-Pay Auctions, May 2005

1474 Ingo Vogelsang, Electricity Transmission Pricing and Performance-Based Regulation, May 2005

1475 Spiros Bougheas and Raymond Riezman, Trade and the Distribution of Human Capital, June 2005

1476 Vesa Kanniainen, Seppo Kari and Jouko Ylä-Liedenpohja, The Start-Up and Growth Stages in Enterprise Formation: The "New View" of Dividend Taxation Reconsidered, June 2005

1477 M. Hashem Pesaran, L. Vanessa Smith and Ron P. Smith, What if the UK had Joined the Euro in 1999? An Empirical Evaluation Using a Global VAR, June 2005

1478 Chang Woon Nam and Doina Maria Radulescu, Effects of Corporate Tax Reforms on SMEs' Investment Decisions under the Particular Consideration of Inflation, June 2005

1479 Panos Hatzipanayotou, Sajal Lahiri and Michael S. Michael, Globalization, CrossBorder Pollution and Welfare, June 2005

1480 John Whalley, Pitfalls in the Use of Ad valorem Equivalent Representations of the Trade Impacts of Domestic Policies, June 2005

1481 Edward B. Barbier and Michael Rauscher, Trade and Development in a Labor Surplus Economy, June 2005

1482 Harrie A. A. Verbon and Cees A. Withagen, Tradable Emission Permits in a Federal System, June 2005

1483 Hendrik Hakenes and Andreas Irmen, On the Long-Run Evolution of Technological Knowledge, June 2005

1484 Nicolas Schmitt and Antoine Soubeyran, A Simple Model of Brain Circulation, June 2005

1485 Carsten Hefeker, Uncertainty, Wage Setting and Decision Making in a Monetary Union, June 2005

1486 Ondřej Schneider and Jan Zápal, Fiscal Policy in New EU Member States - Go East, Prudent Man!, June 2005

1487 Christian Schultz, Virtual Capacity and Competition, June 2005 
1488 Yvan Lengwiler and Elmar Wolfstetter, Bid Rigging - An Analysis of Corruption in Auctions, June 2005

1489 Johannes Becker and Clemens Fuest, Does Germany Collect Revenue from Taxing Capital Income?, June 2005

1490 Axel Dreher and Panu Poutvaara, Student Flows and Migration: An Empirical Analysis, June 2005

1491 Bernd Huber and Marco Runkel, Interregional Redistribution and Budget Institutions under Asymmetric Information, June 2005

1492 Guido Tabellini, Culture and Institutions: Economic Development in the Regions of Europe, July 2005

1493 Kurt R. Brekke and Michael Kuhn, Direct to Consumer Advertising in Pharmaceutical Markets, July 2005

1494 Martín Gonzalez-Eiras and Dirk Niepelt, Sustaining Social Security, July 2005

1495 Alfons J. Weichenrieder, (Why) Do we need Corporate Taxation?, July 2005

1496 Paolo M. Panteghini, S-Based Taxation under Default Risk, July 2005

1497 Panos Hatzipanayotou and Michael S. Michael, Migration, Tied Foreign Aid and the Welfare State, July 2005

1498 Agata Antkiewicz and John Whalley, BRICSAM and the Non-WTO, July 2005

1499 Petr Hedbávný, Ondřej Schneider and Jan Zápal, A Fiscal Rule that has Teeth: A Suggestion for a 'Fiscal Sustainability Council' underpinned by the Financial Markets, July 2005

1500 J. Atsu Amegashie and Marco Runkel, Sabotaging Potential Rivals, July 2005

1501 Heikki Oksanen, Actuarial Neutrality across Generations Applied to Public Pensions under Population Ageing: Effects on Government Finances and National Saving, July 2005

1502 Xenia Matschke, Costly Revenue-Raising and the Case for Favoring Import-Competing Industries, July 2005

1503 Horst Raff and Nicolas Schmitt, Why Parallel Trade may Raise Producers Profits, July 2005

1504 Alberto Bisin and Piero Gottardi, Efficient Competitive Equilibria with Adverse Selection, July 2005

1505 Peter A. Zadrozny, Necessary and Sufficient Restrictions for Existence of a Unique Fourth Moment of a Univariate GARCH(p,q) Process, July 2005 
1506 Rainer Niemann and Corinna Treisch, Group Taxation, Asymmetric Taxation and Cross-Border Investment Incentives in Austria, July 2005

1507 Thomas Christiaans, Thomas Eichner and Ruediger Pethig, Optimal Pest Control in Agriculture, July 2005

1508 Biswa N. Bhattacharyay and Prabir De, Promotion of Trade and Investments between China and India: The Case of Southwest China and East and Northeast India, July 2005

1509 Jean Hindriks and Ben Lockwood, Decentralization and Electoral Accountability: Incentives, Separation, and Voter Welfare, July 2005

1510 Michelle R. Garfinkel, Stergios Skaperdas and Constantinos Syropoulos, Globalization and Domestic Conflict, July 2005

1511 Jesús Crespo-Cuaresma, Balázs Égert and Ronald MacDonald, Non-Linear Exchange Rate Dynamics in Target Zones: A Bumpy Road towards a Honeymoon - Some Evidence from the ERM, ERM2 and Selected New EU Member States, July 2005

1512 David S. Evans and Michael Salinger, Curing Sinus Headaches and Tying Law: An Empirical Analysis of Bundling Decongestants and Pain Relievers, August 2005

1513 Christian Keuschnigg and Martin D. Dietz, A Growth Oriented Dual Income Tax, July 2005

1514 Fahad Khalil, David Martimort and Bruno Parigi, Monitoring a Common Agent: Implications for Financial Contracting, August 2005

1515 Volker Grossmann and Panu Poutvaara, Pareto-Improving Bequest Taxation, August 2005

1516 Lars P. Feld and Emmanuelle Reulier, Strategic Tax Competition in Switzerland: Evidence from a Panel of the Swiss Cantons, August 2005

1517 Kira Boerner and Silke Uebelmesser, Migration and the Welfare State: The Economic Power of the Non-Voter?, August 2005

1518 Gabriela Schütz, Heinrich W. Ursprung and Ludger Wößmann, Education Policy and Equality of Opportunity, August 2005

1519 David S. Evans and Michael A. Salinger, Curing Sinus Headaches and Tying Law: An Empirical Analysis of Bundling Decongestants and Pain Relievers, August 2005

1520 Michel Beine, Paul De Grauwe and Marianna Grimaldi, The Impact of FX Central Bank Intervention in a Noise Trading Framework, August 2005

1521 Volker Meier and Matthias Wrede, Pension, Fertility, and Education, August 2005

1522 Saku Aura and Thomas Davidoff, Optimal Commodity Taxation when Land and Structures must be Taxed at the Same Rate, August 2005 
1523 Andreas Haufler and Søren Bo Nielsen, Merger Policy to Promote 'Global Players'? A Simple Model, August 2005

1524 Frederick van der Ploeg, The Making of Cultural Policy: A European Perspective, August 2005

1525 Alexander Kemnitz, Can Immigrant Employment Alleviate the Demographic Burden? The Role of Union Centralization, August 2005

1526 Baoline Chen and Peter A. Zadrozny, Estimated U.S. Manufacturing Production Capital and Technology Based on an Estimated Dynamic Economic Model, August 2005

1527 Marcel Gérard, Multijurisdictional Firms and Governments' Strategies under Alternative Tax Designs, August 2005

1528 Joerg Breitscheidel and Hans Gersbach, Self-Financing Environmental Mechanisms, August 2005

1529 Giorgio Fazio, Ronald MacDonald and Jacques Mélitz, Trade Costs, Trade Balances and Current Accounts: An Application of Gravity to Multilateral Trade, August 2005

1530 Thomas Christiaans, Thomas Eichner and Ruediger Pethig, A Micro-Level 'Consumer Approach' to Species Population Dynamics, August 2005

1531 Samuel Hanson, M. Hashem Pesaran and Til Schuermann, Firm Heterogeneity and Credit Risk Diversification, August 2005

1532 Mark Mink and Jakob de Haan, Has the Stability and Growth Pact Impeded Political Budget Cycles in the European Union?, September 2005

1533 Roberta Colavecchio, Declan Curran and Michael Funke, Drifting Together or Falling Apart? The Empirics of Regional Economic Growth in Post-Unification Germany, September 2005

1534 Kai A. Konrad and Stergios Skaperdas, Succession Rules and Leadership Rents, September 2005

1535 Robert Dur and Amihai Glazer, The Desire for Impact, September 2005

1536 Wolfgang Buchholz and Wolfgang Peters, Justifying the Lindahl Solution as an Outcome of Fair Cooperation, September 2005

1537 Pieter A. Gautier, Coen N. Teulings and Aico van Vuuren, On-the-Job Search and Sorting, September 2005

1538 Leif Danziger, Output Effects of Inflation with Fixed Price- and Quantity-Adjustment Costs, September 2005

1539 Gerhard Glomm, Juergen Jung, Changmin Lee and Chung Tran, Public Pensions and Capital Accumulation: The Case of Brazil, September 2005 